\title{
Review of herbal medicine works in the avian species
}

\author{
Tyagita Hartady ${ }^{1,2}$, Mas Rizky A. A. Syamsunarno² (iD, Bambang Pontjo Priosoeryanto ${ }^{3}$, S. Jasni ${ }^{4}$ (D) \\ and Roostita L. Balia1,5(D)
}

\begin{abstract}
1. Study Program of Veterinary Medicine, Faculty of Medicine, Universitas Padjadjaran, Jatinangor, Indonesia;
2. Department of Biomedical Sciences, Faculty of Medicine, Universitas Padjadjaran, Jatinangor, Indonesia;

3. Department of Clinic Reproduction Pathology, Faculty of Veterinary Medicine, Bogor Agricultural University, Bogor,

Indonesia; 4. Department of Paraclinical, Faculty of Veterinary Medicine, Universiti Malaysia Kelantan, Kelantan,

Malaysia; 5. Department of Public Health, Faculty of Medicine, Universitas Padjadjaran, Jatinangor, Indonesia.

Corresponding Author: Tyagita Hartady, e-mail: tyagita@unpad.ac.id

Co-authors: MRAAS: rizky@unpad.ac.id, RLB: roostita.balia@unpad.ac.id, BPP: bpontjo@apps.ipb.ac.id, SJ: jasni@umk.edu.my

Received: 31-05-2021, Accepted: 06-10-2021, Published online: 11-11-2021
\end{abstract}

doi: www.doi.org/10.14202/vetworld.2021.2889-2906 How to cite this article: Hartady T, Syamsunarno MRAA, Priosoeryanto BP, Jasni S, Balia RL (2021) Review of herbal medicine works in the avian species, Veterinary World, 14(11): 2889-2906.

\begin{abstract}
Poultry meat consumption is increasing worldwide but the overuse of antimicrobials for prevention and treatment of diseases has increased antimicrobial resistance (AMR), triggering a major public health issue. To restrict AMR emergence, the government supports the optimization of natural products that are safe and easy to obtain with minimal side effects on poultry, humans, and the environment. Various studies have explored the potential of herbs in animal health for their antiviral, antibacterial, antifungal, antiparasitic, immunomodulatory, antioxidant, and body weight gain properties. Therefore, this study reviewed plants with potential application in avian species by summarizing and discussing the mechanisms and prophylactic/therapeutic potential of these compounds and their plant origin extracts.
\end{abstract}

Keywords: antimicrobial resistance, avian herbal therapy, avian medicinal plants, chicken disease, herbal medicine, poultry herbal medicine.

\section{Introduction}

Poultry meat is consumed worldwide, but the overuse of antimicrobials to prevent and treat diseases in poultry has facilitated the emergence of antimicrobial resistance (AMR) [1]. AMR in poultry is reportedly [2] due to excessive use of antibiotics, including disease prevention programs, treatment of infections, accelerating growth, and increasing production [3]. Antibacterials are equally important drugs for treating human diseases [4]; therefore, AMR emergence in poultry requires discovering safe synthetic antibacterial substitutes.

Developing countries commonly use herbal medicines for treating various diseases [5] and herbs have become popular alternatives for poultry, as natural antibacterial and antifungal [6], antiprotozoal [7,8], antiviral [9], antioxidants, growth promoters, anti-inflammatory, and for increasing immunity and weight [10]. Herbs are potential antimicrobials due to their phenolic components (simple phenols, phenolic acids, quinones, flavones, tannins, and coumarins), terpenoids and essential oils, alkaloids and lectins, and polypeptides [11]. They are also relatively inexpensive with no harmful side effects due to simple

Copyright: Hartady, et al. Open Access. This article is distributed under the terms of the Creative Commons Attribution 4.0 International License (http://creativecommons.org/licenses/ by/4.0/), which permits unrestricted use, distribution, and reproduction in any medium, provided you give appropriate credit to the original author(s) and the source, provide a link to the Creative Commons license, and indicate if changes were made. The Creative Commons Public Domain Dedication waiver (http:// creativecommons.org/publicdomain/zero/1.0/) applies to the data made available in this article, unless otherwise stated. absorption by the body. Hence, traditional remedies are widely used based on low cost, local availability, and practical application and do not require modern technology, such as refrigeration [12].

Herbs have other benefits in escalating host response to vaccination by inducing infection prevention through controllable procedures [13]. Therefore, the objective of this review is to evaluate in vivo studies on poultry as recommended references for scientists, field practitioners, and pharmaceutical manufacturers for poultry disease prevention and control.

\section{Literature Search}

We used an inductive approach to search electronic research databases and identify topics related to herbal medicine compounds or extracts that affect avian species as antiviral, antibacterial, antifungal, antiparasitic, immunomodulator, antioxidant, and body weight gain agents. We retrieved and reviewed 76 relevant articles investigating components that contribute to herbal medicine action in avian species.

\section{Antiviral}

Viruses are disease-causing agents that easily emerge, mutate, and spread, making them difficult to treat. In the poultry industry, there are several prevalent viral diseases, such as infectious bursal disease, Newcastle disease (ND), and infectious laryngotracheitis. Various vaccines are available to protect from such diseases, but most farmers prefer using herbs, as some believe that vaccination is ineffective. Further, vaccines are expensive, often have no 
guarantee of bird safety, and are not easily accessible and occasionally noxious [14].

Yasmin et al. [15] reported that herbs, such as aloe species, Azadirachta indica (neem) and Commiphora swynnertonii (Burtt), can treat ND. However, aloe species are only effective for disease management rather than treatment, as there were no significantly different effects between treated and untreated groups. Surprisingly, neem leaf extract demonstrated anti- ND virus (NDV) properties by reducing NDV-stimulated splenocyte proliferation in mice compared with uninfected controls, while administering Burtt extract resulted in significantly lower mortality rates based on clinical symptoms and antibody titer.

Ou et al. [16] revealed that combined extracts of Rhizoma Dryopteridis crassirhizomatis and Fructus mume are effective against infectious bursal disease virus (IBDV) infection. The extract combination improved antibody levels and decreased viral load in the targeted organs. Similarly, Camellia sinensis (green tea) is effective for treating avian influenza (AIV) and inclusion body hepatitis-hydropericardium syndrome. Catechins from $C$. sinensis can suppress viral RNA synthesis by inhibiting endonuclease activity of RNA polymerase, thus potentially killing the virus. The interaction between catechins and viral neuraminidase proteins can prevent virus release [17,18].

Oil extract from Nigella sativa oil is suitable as adjuvants for AIV vaccines, as reviewed by Mady et al. [19]. The herbs also improved host response to vaccination. Administration of $N$. sativa oil on 14 days post-avian influenza vaccination stimulated lymphocyte proliferation and immunity development to $86 \%$ phagocytic percent [20]. Further, virgin coconut oil promotes T-lymphocyte production, improving T-helper cells, as well as stimulating antibody production from B-lymphocyte cells against AIV. However, a similar study shows that chicks given a $15 \mathrm{~mL}$ $\mathrm{VCO} / \mathrm{kg}$ diet can diminish lymphocytes [21].

Tannin also has antiviral properties [22]. Latheef et al. [23] investigated the immunomodulatory activity of Withania somnifera, Tinospora cordifolia, and $A$. indica in chicks infected with chicken infectious anemia virus, observing that the herbs effectively resisted virus multiplication and pathogenesis. A combination of extracts of Ocimum sanctum, W. somnifera, Emblica officinalis, T. cordifolia, Mangifera indica, and Asphaltum (shilajit) was effective against AIV H9N2 and IBDV coinfection by enhancing antibody levels, thereby increasing survival rate and body weight gain, as well as reducing the viral load in the bursa of Fabricius [24]. More information about herbal plants with antiviral properties is documented in Table-1.

\section{Antibacterial}

The increasing population of bacteria resistant to antibiotics has threatened the safety of food products, such as chicken, and humans that consume them.
Many studies highlight the antibacterial properties of medicinal plants, which are as important as existing synthetic drugs. This potential has become the basis of increasing interest in choosing medicinal plants as an alternative medicine for poultry.

Tannin contained in Amla (Phyllanthus emblica) fruit powder [25] can kill bacteria by stimulating phagocytic cells [26]. Amla consumption stimulates increased lactic acid by Lactobacilli in the gut, which leads to diminished $\mathrm{pH}$ in the intestine to prevent coliforms from merging themselves within the intestinal mucosa and ultimately reduce tissue damage caused by failure from toxin production [27]. Salvia rosmarinus (rosemary) supplementation of the broiler diet can increase Lactobacilli counts and minimize Escherichia coli levels [28]. Similarly, Hanan [29] reported that Curcuma longa (turmeric) supplementation mitigated the viability of $E$. coli in the cecum, while increased Lactobacilli count affected weight gain.

Lannaon [30] found that herbal combinations of avocado leaves, guava, duhat, Eucalyptus, or tamarind trees can be a potential antibiotic for broiler chickens, which performed better than existing antibiotics. Another study by Mapatac [31] showed that administering guava decoction improved performance of broilers among other plants, namely, avocado (Persea americana) and malunggay (Moringa oleifera) leaves. However, other studies report that consumption of various parts of avocado may show effective antibacterial properties. These leaves and bark extracts contain saponins, tannins, flavonoids, and terpenoids, which are effective against $E$. coli and Staphylococcus aureus [32]. Further, the fruit contains defensin PaDef, which is potent in killing E. coli and $S$. aureus [33], and the seed contains a high phenolic compound effective against E. coli, S. aureus, and Streptococcus agalactiae [34].

The fruits of guava (Psidium guajava) can inhibit the growth of E. coli and Salmonella Typhimurium [35], while duhat (Syzygium cumini) stems contain bioactive compounds, such as flavonoids, tannins, terpenoids, and alkaloids that inhibit the growth of Bacillus amyloliquefaciens, S. aureus, E. coli, and Pseudomonas aeruginosa [36]. Eucalyptus (Eucalyptus globulus L.) leaves contain bioactive compounds, such as tannins, flavonoids, volatile oils, and terpenoids to inhibit the activity of Salmonella, Klebsiella spp., S. Streptococcus A., Proteus spp., and S. aureus [37]. Tamarind (Tamarindus indica) fruit also contains bioactive compounds, such as alkaloids, flavonoids, saponins, and tannins to inhibit the activity of E. coli, Klebsiella pneumoniae, Salmonella paratyphi $A$., and $P$. aeruginosa [38].

Thyme also delayed the growth of E. coli [39] and $S$. Typhimurium [40] in vitro. The essential oil of cinnamon (Cinnamomum zeylanicum) improved antibacterial properties against foodborne bacteria, such as Klebsiella spp., E. coli, Listeria monocytogenes, and Bacillus spp. [41,42]. Moreover, Griggs and 
Table-1: List of herbal extract that acts as antiviral in poultry.

\begin{tabular}{|c|c|c|c|c|c|}
\hline Plants (species) & Botanical name & Parts used & Mode of action & Virus species & Reference \\
\hline $\begin{array}{l}\text { A. indica } \\
\text { C. swynnertonii }\end{array}$ & Neem Burtt & Leaves various parts & $\begin{array}{l}\text { Reducing the } \\
\text { NDV-stimulated } \\
\text { splenocyte proliferation }\end{array}$ & NDV & {$[15]$} \\
\hline D. crassirhizomatis & Mianmaguanzhong & Rhizoma & Improved the antibody & IBDV & {$[16]$} \\
\hline F. mume & Dark plum & Fruits & $\begin{array}{l}\text { level and decreased the } \\
\text { virus load in the targeted } \\
\text { organs. }\end{array}$ & & \\
\hline C. sinensis & Green tea & Leaves & $\begin{array}{l}\text { Suppressed RNA } \\
\text { synthesis by inhibiting the } \\
\text { endonuclease activity of } \\
\text { RNA polymerase }\end{array}$ & $\begin{array}{l}\text { AIV } \\
\text { IBH-HPS }\end{array}$ & {$[17,18]$} \\
\hline N. sativa & Black cumin & Seeds & $\begin{array}{l}\text { Stimulated Iymphocyte } \\
\text { proliferation and } \\
\text { immunity development }\end{array}$ & AIV & {$[19,20]$} \\
\hline Virgin coconut oil & VCO & Dried coconut kernel & $\begin{array}{l}\text { Promoted T-lymphocyte } \\
\text { production resulting } \\
\text { in the improvement } \\
\text { of T-helper cells, as } \\
\text { well as stimulating } \\
\text { antibody production from } \\
\text { B-lymphocyte cells. }\end{array}$ & AIV & {$[21]$} \\
\hline W. somnifera & Ashwagandha & Root & Resist virus multiplication & CIAV & {$[22,23]$} \\
\hline T. cordifolia & Guduchi & Stem & and pathogenesis & & \\
\hline A. indica & Neem & Leaves & & & \\
\hline O. sanctum & Tulsi & Leaves & Enhanced the host & AIV H9N2 and & {$[24]$} \\
\hline W. somnifera & Ashwagandha & Root & antibody levels and & IBDV coinfection & \\
\hline E. officinalis & Malaka/amla & Fruit & depressed the viral load & & \\
\hline T. cordifolia & Giloy & Leaves & in bursa of Fabricius & & \\
\hline M. indica & Mango & Fruit & & & \\
\hline
\end{tabular}

NDV=Newcastle disease virus; IBDV=Infectious bursal disease; AIV=Avian influenza virus; IBH-HPS=Inclusion body hepatitis-hydropericardium syndrome; CIAV=Chicken infectious anemia virus. $C$. sinensis=Camellia sinensis, W. somnifera=Withania somnifera, $T$. cordifolia=Tinospora cordifolia, $A$. indica=Azadirachta indica, O. sanctum=Ocimum sanctum, E. officinalis=Emblica officinalis, M. indica=Mangifera indica, C. swynnertonii=Commiphora swynnertonii, D. crassirhizomatis=Dryopteridis crassirhizomatis, F. mume=Fructus mume

Jacob [43] reported that cinnamon (C. zeylanicum) essential oil has potential natural antibiotic properties in poultry. In addition, Allium sativum, Allium cepa, and Menthe spp. can effectively reduce the growth of E. coli [44]. More information about herbal plants with antibacterial properties is documented in Table-2.

\section{Antifungal}

Aspergillus fumigatus causes frequent respiratory disease in birds called aspergillosis compared with other species, such as Aspergillus flavus, Aspergillus niger, Aspergillus Nidulans, and Aspergillus terreus [45]. Plant extracts contain phenolic compounds as potential antifungal and antiaflatoxigenic agents [46] using various mechanisms, such as inhibiting the production of aflatoxin B1, namely, syringaldehyde, sinapic acid, and acetosyringone [47], and decreasing A. flavus growth by targeting oxidative mitochondrial stress as a defense system using substances such as salicylic acid, thymol, vanillyl acetone, cinnamic acid, and vanillin [48].

Njoki et al. [49] showed that Spinacia oleracea extracts were effective antifungals by diminishing the conidia of toxigenic A. flavus. The extracts had 19.6\% saponins, flavonoids, terpenoids, tannins, alkaloids, and glycosides and the antifungal properties of the extracts of Artemisia dracunculus, Achillea wilhelmsii, Bunium persicum, C. cyminum, Zataria multiflora
Boiss, and Satureja hortensis were studied against A. niger, A. fumigatus, A. flavus [50], and Candida albicans [51]. Among the extracts tested, A. wilhelmsii and Z. multiflora Boiss were the most effective antifungals. Plant extracts contained phenolic isomers, namely, thymol and carvacrol.

Furthermore, other avian pathogenic fungi, such as Alternaria spp., were successfully inhibited by Salvia sclarea, Salvia officinalis, and Rosmarinus officinalis extracts [52]. The fungistatic and fungicidal mechanisms involved synthesizing bioactive organic compounds [53], as well as antifungal protein [54] and peptide [55].

The seeds and fruit extract of Carum copticum can be effective against Aspergillus spp. by inhibiting growth [56]. Further, leaf extract of Satureja bachtiarica contains thymol and $\gamma$-terpinene that can limit the growth of C. albicans, Candida krusei, and Kennedia glabrata [57]. The combination of Prosopis spicigera, Zingiber officinale, and Trachyspermum ammi are rich in alkaloids, amino acids, protein, sterols, and terpenes that are toxic toward C. albicans, C. krusei, C. tropicalis, and Candida glabrata [58]. The aromatic ring and the presence of free phenol hydroxyl of Mentha piperita and Thymus vulgaris L. formulation activity can damage fungal cell walls and membranes, such as Aspergillus, Penicillium spp., Fusarium, and Saccharomyces [59]. 
Table-2: List of herbal extract that acts as antibacterial in poultry.

\begin{tabular}{|c|c|c|c|c|c|}
\hline $\begin{array}{l}\text { Plants } \\
\text { (species) }\end{array}$ & $\begin{array}{l}\text { Botanical } \\
\text { name }\end{array}$ & Parts used & Mode of action & Bacteria species & Reference \\
\hline P. emblica & Amla & Fruit & $\begin{array}{l}\text { Stimulating phagocytic cells, } \\
\text { Increased Lactobacilli population } \\
\text { in gut, } \\
\text { Failure of bacterial colonization in } \\
\text { intestine }\end{array}$ & Coliforms & {$[25-27]$} \\
\hline S. rosmarinus & Rosemary & Leaves & $\begin{array}{l}\text { Increased the Lactobacilli counts } \\
\text { and minimized E. coli level }\end{array}$ & E. coli & [28] \\
\hline C. longa & Turmeric & Rhizome & $\begin{array}{l}\text { Increased the Lactobacilli counts } \\
\text { and minimized } E \text {. coli level }\end{array}$ & E. coli & [29] \\
\hline \multirow[t]{3}{*}{$\begin{array}{l}\text { P. americana } \\
\text { Mill }\end{array}$} & Avocado & $\begin{array}{l}\text { Leaves and } \\
\text { bark }\end{array}$ & $\begin{array}{l}\text { Role of bioactive compounds such } \\
\text { as saponins, tannins, flavonoids, } \\
\text { and terpenoids }\end{array}$ & E. coli, S. aureus & {$[32]$} \\
\hline & & Fruit & $\begin{array}{l}\text { Defensin PaDef as antimicrobial } \\
\text { peptides }\end{array}$ & E. coli, S. aureus & [33] \\
\hline & & Seed & $\begin{array}{l}\text { Phenolic compounds as well } \\
\text { documented antimicrobial }\end{array}$ & $\begin{array}{l}\text { E. coli, S. aureus, } \\
\text { S. agalactiae }\end{array}$ & {$[34]$} \\
\hline P. guajava & Guava & Fruit & Inhibit the growth of bacteria & $\begin{array}{l}\text { E. coli, S. } \\
\text { Typhimurium }\end{array}$ & {$[35]$} \\
\hline S. cumini & Duhat & Stem & $\begin{array}{l}\text { The bioactive such as flavonoids, } \\
\text { tannin, terpenoid, and alkaloid } \\
\text { inhibits the growth of bacteria }\end{array}$ & $\begin{array}{l}\text { B. amyloliquefaciens, } \\
\text { S. aureus, E. coli, } \\
\text { P. aeruginosa }\end{array}$ & {$[36]$} \\
\hline E. globulus L. & Eucalyptus & Leaves & $\begin{array}{l}\text { The bioactive properties such as } \\
\text { tannin, flavonoids, volatile oils, } \\
\text { and terpenoids inhibit bacterial } \\
\text { activity }\end{array}$ & $\begin{array}{l}\text { Salmonella, } \\
\text { Klebsiella spp., } \\
\text { S. Streptococcus } \\
\text { A., Proteus spp., } \\
\text { S. aureus }\end{array}$ & [37] \\
\hline T. indica & Tamarind & Fruits & $\begin{array}{l}\text { The bioactive properties such as } \\
\text { alkaloid, flavonoid, saponin, and } \\
\text { tannin inhibit bacterial activity }\end{array}$ & $\begin{array}{l}\text { E. coli, K. } \\
\text { pneumoniae, } \\
\text { S. paratyphi A., } \\
\text { P. aeruginosa. }\end{array}$ & {$[38]$} \\
\hline T. vulgaris & Thyme & Leaves & Delayed the growth of bacteria & $\begin{array}{l}\text { E. coli, } S \text {. } \\
\text { Typhimurium }\end{array}$ & {$[39,40]$} \\
\hline C. zeylanicum & Cinnamon & Inner bark & $\begin{array}{l}\text { Improved the antibacterial } \\
\text { properties against foodborne } \\
\text { bacteria }\end{array}$ & $\begin{array}{l}\text { Klebsiella } \\
\text { spp., E. coli, L. } \\
\text { monocytogenes, and } \\
\text { Bacillus spp. }\end{array}$ & {$[41,42,43]$} \\
\hline A. sativum & Garlic & Bulbs & Inhibit the growth of bacteria & E. coli & [44] \\
\hline A. сера & Mint & Leaves & & & \\
\hline Menthe spp. & Onion & Leaves & & & \\
\hline
\end{tabular}

S. rosmarinus=Salvia rosmarinus, E. coli=Escherichia coli, C. longa=Curcuma longa, $P$. americana=Persea americana, S. aureus=Staphylococcus aureus, S. agalactiae=Streptococcus agalactiae, $P$. guajava=Psidium guajava, Salmonella Typhimurium: S. Typhimurium, S. cumini=Syzygium cumini, B. amyloliquefaciens=Bacillus amyloliquefaciens, $P$. aeruginosa $=$ Pseudomonas aeruginosa, E. globulus=Eucalyptus globulus, $T$. indica=Tamarindus indica, K. pneumonia=Klebsiella pneumonia, S. paratyphi $A=$ Salmonella paratyphi $A$, C. zeylanicum=Cinnamomum zeylanicum, L. monocytogenes=Listeria monocytogenes, A. sativum=Allium sativum, A. cepa=Allium cepa, T. vulgaris=Thymus vulgaris, $P$. emblica= Phyllanthus emblica

Similarly, oil extracts of Z. multiflora Boiss, Cinnamomum verum, and Pimpinella anisum can inhibit the growth of C. albicans, A. flavus, A. niger, and A. fumigatus [60]. The combination of Mentha arvensis, $O$. sanctum, and $A$. sativum was potent in preventing the growth of mycelial cells of A. fumigatus, Aspergillus parasiticus, and Penicillium spp. [61]. Allicin content of Allium tuncelianum is a toxigenic agent against C. albicans and Malassezia pachydermatis [62]. Similarly, the production of aflatoxin $\mathrm{B} 1$ of $A$. flavus was stopped by C. longa L. [63]. Further herbal extract studies on antifungal properties in poultry are listed in Table-3.

\section{Antiparasitic}

\section{Antiprotozoal}

Antiprotozoal works by destroying the protozoa itself or inhibiting their growth and reproductive capabilities. Some commercial drugs, such as mebendazole, metronidazole, nitroimidazole dimetridazole, ornidazole, tinidazole, monensin, salinomycin, and semduramycin, have been regulated in many countries. Since then, diseases caused by protozoa has increased and resulted in economic losses.

Habibi et al. [64] observed that consumption of Nectaroscordum tripedale with diclazuril leads to improved growth performance, lesion score, the extent of bloody diarrhea, and oocyst count in individuals infected by Eimeria tenella. The herb can promote body mass gain and has previously been shown to alleviate lesion scores in birds compared with the control group.

Muthamilselvan et al. [65] evaluated other anticoccidial herbs, including Artemisia annua, pine bark, A. sativum, and $C$. sinensis. A. annua contains artemisinin that can stimulate reactive oxygen 
Table-3: List of herbal extract that acts as antifungal in poultry.

\begin{tabular}{|c|c|c|c|c|c|}
\hline Plants (species) & $\begin{array}{l}\text { Botanical } \\
\text { name }\end{array}$ & Parts used & Mode of action & Fungi species & Reference \\
\hline S. oleracea & Spinach & Leaves & $\begin{array}{l}\text { Diminishing the conidia of } \\
\text { toxigenic fungus }\end{array}$ & A. flavus & [49] \\
\hline $\begin{array}{l}\text { A. wilhelmsii, } \\
\text { Z. multiflora Boiss }\end{array}$ & $\begin{array}{l}\text { Yarrow, } \\
\text { Shirazi thyme }\end{array}$ & Flower & Inhibit the growth of fungus & $\begin{array}{l}\text { A. niger, } \\
\text { A. fumigatus, and } \\
\text { A. flavus } \\
\text { Candida albicans }\end{array}$ & $\begin{array}{l}{[50]} \\
{[51]}\end{array}$ \\
\hline $\begin{array}{l}\text { S. sclarea } \\
\text { S. officinalis } \\
\text { R. officinalis }\end{array}$ & $\begin{array}{l}\text { Clary sage } \\
\text { Sage } \\
\text { Rosemary }\end{array}$ & Leaves & $\begin{array}{l}\text { Synthesis of the compounds of } \\
\text { bioactive organic, also antifungal } \\
\text { protein and peptide }\end{array}$ & Alternaria spp. & {$[52-55]$} \\
\hline C. copticum & Ajwain & $\begin{array}{l}\text { Seeds, } \\
\text { fruits }\end{array}$ & Inhibit the growth of fungus & Aspergillus spp. & {$[56]$} \\
\hline S. bachtiarica & Savory & Leaves & $\begin{array}{l}\text { Thymol and } \gamma \text {-terpinene are able } \\
\text { to inhibit the growth of fungus }\end{array}$ & $\begin{array}{l}\text { C. albicans, } \\
\text { C. krusei, K. glabrata }\end{array}$ & {$[57]$} \\
\hline $\begin{array}{l}\text { P. spicigera } \\
\text { Z. officinale } \\
\text { T. ammi }\end{array}$ & $\begin{array}{l}\text { Khejri } \\
\text { Ginger } \\
\text { Ajwain }\end{array}$ & $\begin{array}{l}\text { Leaves } \\
\text { Roots } \\
\text { Seeds }\end{array}$ & $\begin{array}{l}\text { The phytoconstituents such as } \\
\text { alkaloids, amino acids, protein, } \\
\text { sterols, and terpenes }\end{array}$ & $\begin{array}{l}\text { C. albicans, C. krusei, } \\
\text { C. tropicalis, } \\
\text { C. glabrata }\end{array}$ & {$[58]$} \\
\hline $\begin{array}{l}\text { M. piperita } \\
\text { T. vulgaris L. }\end{array}$ & $\begin{array}{l}\text { Peppermint } \\
\text { thyme }\end{array}$ & Oil & $\begin{array}{l}\text { The aromatic ring and the } \\
\text { presence of the free phenol } \\
\text { hydroxyl activity leads to the } \\
\text { damage of fungal cell wall and } \\
\text { cell membrane }\end{array}$ & $\begin{array}{l}\text { Aspergillus, } \\
\text { Penicillium } \\
\text { spp., Fusarium, } \\
\text { Saccharomyces }\end{array}$ & {$[59]$} \\
\hline $\begin{array}{l}\text { Z. multiflora Boiss } \\
\text { C. verum } \\
\text { P. anisum }\end{array}$ & $\begin{array}{l}\text { Thyme } \\
\text { Cinnamon } \\
\text { Anise }\end{array}$ & Oil & $\begin{array}{l}\text { Inhibit the growth of isolated } \\
\text { fungal }\end{array}$ & $\begin{array}{l}\text { C. albicans, } \\
\text { A. flavus, A. niger. } \\
\text { A. fumigatus }\end{array}$ & {$[60]$} \\
\hline M. arvensis & Mint & Leaves & Inhibit the mycelial growth of & A. fumigatus, & {$[61]$} \\
\hline $\begin{array}{l}\text { O. sanctum } \\
\text { A. sativum }\end{array}$ & $\begin{array}{l}\text { Tulsi } \\
\text { Garlic }\end{array}$ & $\begin{array}{l}\text { Leaves } \\
\text { Bulbs }\end{array}$ & fungus & $\begin{array}{l}\text { A. parasiticus, } \\
\text { Penicillium spp. }\end{array}$ & \\
\hline A. tuncelianum & Tunceli garlic & Bulbs & $\begin{array}{l}\text { The allicin substance is able to } \\
\text { inhibit the growth of fungus }\end{array}$ & $\begin{array}{l}\text { C. albicans, } \\
\text { M. pachydermatis }\end{array}$ & {$[62]$} \\
\hline C. longa $L$. & Turmeric & Rhizomes & $\begin{array}{l}\text { Inhibit fungus activity and } \\
\text { prevent the production of } \\
\text { Aflatoxin } B 1\end{array}$ & A. flavus & {$[63]$} \\
\hline
\end{tabular}

C. longa =Curcuma longa, $A$. sativum=Allium sativum, A. fumigatus=Aspergillus fumigatus, $A$. flavus=Aspergillus flavus, A. niger=Aspergillus niger, S. oleracea=Spinacia oleracea, A. wilhelmsii=Achillea wilhelmsii, S. sclarea=Salvia sclarea, S. officinalis=Salvia officinalis, $R$. officinalis=Rosmarinus officinalis, $C$. copticum=Carum copticum,

C. krusei=Candida krusei, C. glabrata=Candida glabrata, K. glabrata=Kennedia glabrata, P. spicigera=Prosopis spicigera, T. ammi=Trachyspermum ammi, M. piperita=Mentha piperita, T. vulgaris=Thymus vulgaris, C. verum=Cinnamomum verum, $P$. anisum=Pimpinella anisum, M. arvensis=Mentha arvensis, A. parasiticus: Aspergillus parasiticus,

M. pachydermatis=Malassezia pachydermatis, S. bachtiarica=Satureja bachtiarica, $A$. tuncelianum=Allium tuncelianum, Z. officinale=Zingiber officinale

species to inhibit $E$. tenella sporulation and cell wall formation [66]. Further, sulfur content of $A$. sativum is effective in preventing E. tenella sporulation. Pine bark extract contains condensed tannins that influx the wall of oocytes, damage the cytoplasm, and inactivate endogenous enzymes responsible for the sporulation mechanism. Sporocytes in oocytes then turn abnor$\mathrm{mal}$ and lead to diminished sporulation of oocytes in E. tenella, Eimeria Maxima, and Eimeria acervulina [67]. Selenium and polyphenol substances of C. sinensis are also effective anti-coccidiosis agents leveraging the same mechanism [68]. Further, previous reports show that allicin of $A$. sativum can effectively inhibit the sporulation of E. tenella [69]. N-3 fatty acids, flavonoids, and vernoside extracted from Linum usitatissimum [70], Ageratum conyzoides [71], and Vernonia amygdalina [72] are also potential herbs for the same parasites. A previous study reported that Carica papaya (papain) leaves [73] and saponin and betaine source plants (Cyamopsis tetragonoloba, Mesembryanthemum cordifolium, Morinda citrifolia, and Malvaviscus arboreus) lysed oocysts and protected the epithelial cells [74]. The essential oils of Origanum vulgare, olive leave extract, grape seed extract, guar, T. vulgaris, turmeric, and clove extract are also effective in destroying parasites [75].

The coccidiostat effect was also studied by Christaki et al. [76] who extracted apacox from the combination of Agrimonia eupatoria, Echinacea angustifolia, Ribes nigrum, and Cinchona succirubra, showing a coccidiostatic effect on E. tenella, despite the effect being significantly lower than the control group. Furthermore, Gefu et al. [77] showed that onion (A. серa) is a potential antiparasitic against protozoa, such as Leishmania spp. The parasite was successfully eradicated after onion extract was administered at a $1.25 \mathrm{mg} / \mathrm{mL}$ dose [78]. The pronounced antiprotozoal activity of onion is due to the sulfur compound alliin and its ability to treat lesions caused by protozoa [79].

Histomonas meleagridis is protozoa causing high mortality and morbidity in poultry. A study by Hafez and Hauck [80] reported that essential oils combining C. verum, A. sativum, Citrus limon, and S. rosmarinus provide prophylactic effects that can diminish 
mortality in infected animals. The herbal properties as an antiprotozoal agent in poultry are summarized in Table-4.

\section{Anthelmintic}

The residual effects on chicken meat or eggs due to drug consumption and reducing synthetic drug use in chickens are pertinent issue, which not only causes resistance but also incurs additional residual impacts that endanger humans and the environment. Pumpkin oil (Cucurbita pepo L.) acts as an anthelmintic, as well as a natural laxative, by reducing helminth count and egg output $[81,82]$. Consumption of myrrh and thyme can also kill helminths, such as Trichinella spiralis [83]. Administering onion oil at

Table-4: List of herbal extract that acts as antiprotozoal in poultry.

\begin{tabular}{|c|c|c|c|c|c|}
\hline Plants (species) & $\begin{array}{l}\text { Botanical } \\
\text { name }\end{array}$ & Parts used & Mode of action & $\begin{array}{l}\text { Protozoa } \\
\text { species }\end{array}$ & Reference \\
\hline $\begin{array}{l}\text { N. tripedale with } \\
\text { diclazuril }\end{array}$ & $\begin{array}{l}\text { Sicilian honey } \\
\text { garlic }\end{array}$ & Bulbs & $\begin{array}{l}\text { Improved growth } \\
\text { performance, lesion } \\
\text { score, extent of bloody } \\
\text { diarrhea, and oocyst } \\
\text { count in infected group } \\
\text { by protozoa }\end{array}$ & E. tenella & {$[64]$} \\
\hline A. annua & Artemisinin & Leaves & $\begin{array}{l}\text { Inhibit the sporulation } \\
\text { of protozoa }\end{array}$ & E. tenella & {$[65,66]$} \\
\hline P. radiata & Pine & Bark & & $\begin{array}{l}\text { E. tenella, } \\
\text { E. acervuline, } \\
\text { A. maxima }\end{array}$ & {$[67]$} \\
\hline C. sinensis & Tea plant & Leaves & & $\begin{array}{l}\text { E. tenella, } \\
\text { E. acervuline, } \\
\text { A. maxima }\end{array}$ & {$[68]$} \\
\hline A. sativum & Garlic & Bulb & & $\begin{array}{l}\text { E. tenella, } \\
\text { E. acervuline, } \\
\text { A. maxima }\end{array}$ & {$[69]$} \\
\hline L. usitatissimum & Flax & Seed & $\begin{array}{l}N-3 \text { fatty acids } \\
\text { suppressed the } \\
\text { development in } \\
\text { schizogony stage }\end{array}$ & E. tenella & {$[70]$} \\
\hline A. conyzoides & $\begin{array}{l}\text { Billy goat } \\
\text { weed }\end{array}$ & Leaves & $\begin{array}{l}\text { Flavonoids suppressed } \\
\text { the development in } \\
\text { schizogony stage }\end{array}$ & E. tenella & [71] \\
\hline V. amygdalina & Delile & Leaves & $\begin{array}{l}\text { Inhibit the sporulation } \\
\text { of oocysts }\end{array}$ & E. tenella & {$[72]$} \\
\hline C. papaya & Papain & Leaves & $\begin{array}{l}\text { Stimulate host } \\
\text { immunity and disturb } \\
\text { the oocyst formation }\end{array}$ & E. tenella & {$[73]$} \\
\hline C. tetragonoloba & Guar & Bean & & E. tenella & {$[74]$} \\
\hline M. cordifolia & Baby sun rose & Leaves & $\begin{array}{l}\text { Lysed the oocysts and } \\
\text { protected the epithelial } \\
\text { cells }\end{array}$ & E. tenella & [74] \\
\hline M. citrifolia & Noni & Fruits & $\begin{array}{l}\text { Lysed the oocysts and } \\
\text { protected the epithelial } \\
\text { cells }\end{array}$ & E. tenella & {$[74]$} \\
\hline \multirow[t]{2}{*}{ M. arboreus } & Wax mallow & Leaves & $\begin{array}{l}\text { Lysed the oocysts and } \\
\text { protected the epithelial } \\
\text { cells }\end{array}$ & E. tenella & {$[74]$} \\
\hline & & & $\begin{array}{l}\text { Lysed the oocysts and } \\
\text { protected the epithelial } \\
\text { cells }\end{array}$ & E. tenella & {$[74]$} \\
\hline O. vulgare & Oregano & $\begin{array}{l}\text { Dried leaves, } \\
\text { essential oil }\end{array}$ & $\begin{array}{l}\text { Destruction of } \\
\text { sporozoite membrane } \\
\text { and suppression of } \\
\text { oocyst production }\end{array}$ & Various species & {$[75]$} \\
\hline O. europaea & Olive leave & Leaves & $\begin{array}{l}\text { Anti-inflammatory and } \\
\text { anti }\end{array}$ & E. tenella & {$[75]$} \\
\hline V. vinifera & Grape & Seed & Oxidative stress & E. tenella & {$[75]$} \\
\hline C. tetragonoloba & Guar & Bean & $\begin{array}{l}\text { Damage the cell } \\
\text { membrane }\end{array}$ & E. tenella & {$[75]$} \\
\hline T. vulgaris & Thyme & Leaves & Destroy the oocysts & E. tenella & {$[75]$} \\
\hline C. longa $L$. & Turmeric & Rhizomes & $\begin{array}{l}\text { Damage the sporozoite } \\
\text { membranes }\end{array}$ & E. tenella & {$[75]$} \\
\hline S. aromaticum & Clove & Leaves & Damage the oocytes & E. tenella & {$[75]$} \\
\hline
\end{tabular}


Table-4: (Continued).

\begin{tabular}{|c|c|c|c|c|c|}
\hline Plants (species) & $\begin{array}{l}\text { Botanical } \\
\text { name }\end{array}$ & Parts used & Mode of action & $\begin{array}{l}\text { Protozoa } \\
\text { species }\end{array}$ & Reference \\
\hline A. eupatoria & Agrimony & Leaves & $\begin{array}{l}\text { Enhancing body weight } \\
\text { gain and value of feed } \\
\text { conversion ratio }\end{array}$ & E. tenella & {$[76]$} \\
\hline E. angustifolia & $\begin{array}{l}\text { Purple } \\
\text { coneflower }\end{array}$ & Petals & $\begin{array}{l}\text { Enhancing body weight } \\
\text { gain and value of feed } \\
\text { conversion ratio }\end{array}$ & E. tenella & {$[76]$} \\
\hline R. nigrum & Blackcurrant & $\begin{array}{l}\text { Seed, leaves, } \\
\text { fruit }\end{array}$ & $\begin{array}{l}\text { Enhancing body weight } \\
\text { gain and value of feed } \\
\text { conversion ratio }\end{array}$ & E. tenella & {$[76]$} \\
\hline C. succirubra & Quina & Bark & $\begin{array}{l}\text { Enhancing body weight } \\
\text { gain and value of feed } \\
\text { conversion ratio }\end{array}$ & E. tenella & {$[76]$} \\
\hline A. сера & Onion & Bulbs & $\begin{array}{l}\text { The sulfur compound } \\
\text { allicin is able to } \\
\text { eradicate the protozoa } \\
\text { and its ability to treat } \\
\text { the lesion caused by } \\
\text { the protozoa }\end{array}$ & $\begin{array}{l}\text { Leishmania } \\
\text { spp. }\end{array}$ & {$[77,78,79]$} \\
\hline $\begin{array}{l}\text { C. verum } \\
\text { A. sativum } \\
\text { C. limon } \\
\text { S. rosmarinus }\end{array}$ & $\begin{array}{l}\text { Cinnamon } \\
\text { Garlic } \\
\text { Lemon } \\
\text { Rosemary }\end{array}$ & Oils & $\begin{array}{l}\text { The essential oils } \\
\text { contain prophylactic } \\
\text { effect that able to } \\
\text { diminish mortality in } \\
\text { infected animals }\end{array}$ & H. meleagridis & {$[80]$} \\
\hline
\end{tabular}

C. sinensis=Camellia sinensis, S. rosmarinus=Salvia rosmarinus, C. longa=Curcuma longa, $A$. sativum=Allium sativum, A. cepa=Allium cepa, T. vulgaris=Thymus vulgaris, C. verum=Cinnamomum verum, E. tenella=Eimeria tenella, A. annua =Artemisia annua, L. usitatissimum=Linum usitatissimum, A. conyzoides=Ageratum conyzoides, V. amygdalina=Vernonia amygdalina, C. tetragonoloba=Cyamopsis tetragonoloba, M. citrifolia=Morinda citrifolia, M. arboreus=Malvaviscus arboreus, O. vulgare=Origanum vulgare, $A$. eupatoria=Agrimonia eupatoria, E. angustifolia=Echinacea angustifolia, R. nigrum=Ribes nigrum, C. succirubra=Cinchona succirubra, $H$. meleagridis=Histomonas meleagridis, $C$. limon=Citrus limon, $P$. radiate=Pinus radiate, $V$. vinifera=Vitis vinifera, S. aromaticum $=$ Syzygium aromaticum

a concentration of $5 \mathrm{mg} / \mathrm{kg} /$ day is potent on mature worms and the cystic stage of T. spiralis, which can also enhance protective antibodies against the parasite [84]. In 2003, Zenner et al. [85] studied the influence of cinnamon oil on Trichomonas and H. meleagridis [85]. The oil contains trans-cinnamaldehyde and proanthocyanidins that promote its anthelmintic effects [86], disrupting the intestinal tissue of the parasites.

Both in vitro and in vivo studies have explored the anthelmintic activity of leaf extracts of Tephrosia vogelii and $V$. amygdalina against $A$. galli infections. The plant extracts comprise chemical elements, such as rotenoids, lactones, sesquiterpene, glycosides, tannins, and anthracenes, which all showed significant anthelmintic activity $(\mathrm{p}<0.05)$ against $A$. galli. The in vitro study demonstrated that both extracts effectively inhibited $74.7 \%$ and $63.7 \%$ of larval migration, respectively, while fecal egg counts decreased by $77.4 \%$ and $76.9 \%$, respectively [87]. Other plants also target the same helminth. Papaya (C. papaya) extracts are effective anthelmintics against the growth of $A$. galli eggs due to proteolytic enzymes, such as papain, chymopapain, and lysozymes found in the latex, as well as the leaves [88]. Here, papain inhibited all developmental stages of the parasite. The study also suggested that the dust of bishkatali leaves can inhibit the development of $A$. galli eggs. The table below provides detailed information on various plants that act as anthelmintics in poultry (Table-5).

\section{Lice and mice}

The use of chemical insecticides may harm birds since the toxic effects directly jeopardize birds and possibly contaminate chicken meat. Jacob and Pescatore [89] proved that the aqueous extract of garlic and cinnamon oil kills lice and mice infestations in chickens, including Trichomonas, H. meleagridis, and head lice. Other herbal products effective against lice infestation in poultry include $2 \%$ aqueous solution of Pestoban [90] at a 1:30 dilution [91]. Another study showed that garlic extracts killed $96.5 \%$ of Dermanyssus gallinae infestation in layer farms [92] and mites show overall body damage under scanning electron microscope examination, including darkened leg coloring. Unfortunately, no further information exists on histopathological changes to mites induced by herbs. Pumnuan et al. [93] suggested that clove essential oil is a natural insecticide to control chicken lice (Lipeurus caponis L.), while spices such as Annona senegalensis, Tectona grandis, Securidaca longepedunculata, Indigofera hirsuta, Lophira lanceolata, Hyptis spicigera, Steganotaenia araliacea, Oxytenanthera abyssinica, Nicotiana tabacum, Jatropha curcas, Ficus exasperata, A. indica, and Parkia biglobosa are effective insecticides, with $A$. senegalensis being the most popular endogenous plant in controlling ectoparasites in backyard poultry [94]. Table-6 describes herbs having anti-ectoparasite properties for poultry (Table-6). 
Table-5: List of herbal extract that acts as anthelmintic in poultry.

\begin{tabular}{|c|c|c|c|c|c|}
\hline Plants (species) & $\begin{array}{l}\text { Botanical } \\
\text { name }\end{array}$ & Parts used & Mode of action & $\begin{array}{l}\text { Helminths } \\
\text { species }\end{array}$ & References \\
\hline C. pepo L. & Pumpkin & Seeds & $\begin{array}{l}\text { Decrease the worm count and } \\
\text { eggs output of the worm }\end{array}$ & $\begin{array}{l}\text { Ascaridia spp., } \\
\text { Raillietina } \\
\text { spp., Heterakis } \\
\text { spp. }\end{array}$ & {$[81,82]$} \\
\hline $\begin{array}{l}\text { C. myrrha and } \\
\text { T. vulgaris }\end{array}$ & $\begin{array}{l}\text { Myrrh and } \\
\text { thyme }\end{array}$ & $\begin{array}{l}\text { Resin of the } \\
\text { bark, leaves }\end{array}$ & Decrease the worm count & T. spiralis & {$[83]$} \\
\hline N. sativa and $A$. cepa & Onion & $\begin{array}{l}\text { Bulb extract } \\
\text { oil }\end{array}$ & $\begin{array}{l}\text { Potent on the mature worms } \\
\text { and cystic stage of the worm, } \\
\text { also improving the protective } \\
\text { antibodies against the } \\
\text { parasite }\end{array}$ & T. spiralis & [84] \\
\hline C. verum & Cinnamon & Oil & $\begin{array}{l}\text { The oil contains } \\
\text { trans-cinnamaldehyde and } \\
\text { proanthocyanidins disrupting } \\
\text { the intestinal tissue of the } \\
\text { parasites }\end{array}$ & $\begin{array}{l}\text { Trichomonas } \\
\text { and } H \text {. } \\
\text { meleagridis }\end{array}$ & {$[85]$} \\
\hline $\begin{array}{l}\text { T. vogelii and } \\
\text { V. amygdalina }\end{array}$ & $\begin{array}{l}\text { Vogel } \\
\text { Tephrosia } \\
\text { and Delile }\end{array}$ & Leaves & $\begin{array}{l}\text { The plant extracts consist } \\
\text { of chemical elements such } \\
\text { as rotenoids, lactones, } \\
\text { sesquiterpene, glycosides, } \\
\text { tannins, and anthracenes, } \\
\text { which all showed significant } \\
\text { anthelmintic activity against } \\
\text { the worm. Inhibited larval } \\
\text { migration, while fecal egg } \\
\text { counts were reduced }\end{array}$ & A. galli & {$[86]$} \\
\hline C. papaya & Papaya & $\begin{array}{l}\text { Latex and } \\
\text { leaves }\end{array}$ & $\begin{array}{l}\text { Suppress the growth of } \\
\text { the worm and inhibit all } \\
\text { developmental stages of the } \\
\text { parasite due to proteolytic } \\
\text { enzymes such as papain, } \\
\text { chymopapain, and lysozymes }\end{array}$ & A. galli & {$[87]$} \\
\hline Pale persicaria & Bishkatali & Leaves & $\begin{array}{l}\text { Inhibit the development of the } \\
\text { eggs of the worm }\end{array}$ & A. galli & {$[88]$} \\
\hline
\end{tabular}

N. sativa =Nigella sativa, $A$. cepa =Allium cepa, T. vulgaris $=$ Thymus vulgaris, C. verum=Cinnamomum verum, V. amygdalina=Vernonia amygdalina, C. papaya=Carica papaya, H. meleagridis=Histomonas meleagridis, C. pepo=Cucurbita pepo, T. spiralis=Trichinella spiralis, T. vogelii=Tephrosia vogelii, C. myrrha=Commiphora myrrha

\section{Immunomodulator}

Medicinal plants contain compounds to stimulate immunity. Plant extracts have been recommended as immunomodulators due to their effects on the animal immune system related to phytochemicals, such as flavonoids, polysaccharides, lactones, alkaloids, diterpenoids, and glycosides. Many medicinal plants show less toxic side effects; hence, they are considered a safe treatment compared to synthetic therapy.

In poultry, plant extracts containing a mixture of cinnamaldehyde, carvacrol, and capsicum oleoresin as immunomodulators, showed regression of $\mathrm{CD}_{40}$ LG, interferon (IFN)-G, and interleukin (IL)-6, indicating low inflammation, especially in the digestive tracts against avian coccidiosis caused by intestinal protozoan parasites and Eimeria spp. [95]. The overall effects were confirmed by higher levels of serum antibodies and enhanced pro-inflammatory cytokine production in the duodenum.

Another study on the role of Astragalus membranaceus as an immunomodulator showed improved immune activity in broiler chicks infected with lipopolysaccharide [96]. The study showed that the immune organ weight and IgG level increased, while liver and kidney functions improved. The plant also stimulated the growth of fecal microorganism composition. Tan and Vanitha [97] reported that Aloe vera leaves contain CARN750 that selectively stimulates immunomodulatory substances, such as cytokine and lymphocytes, while the roots and leaves of Panax ginseng are rich in saponin can effectively stimulate lymphocytes, cytokine, and IL-6 to improve macrophage performance. The herbs offered potential resistance to viral infections in birds by stimulating macrophage production, as well as T-cell-mediated immune responses and stimulating macrophages through TLR6 signaling and NF kappa B translocation, leading to cytokine production. The hematological profile also improved after synthesizing more hemoglobin in the bone marrow after hepatic cells released erythropoietic factors. In a study of 42-day-old broilers given sheep red blood cells, turmeric rhizome powder improved blood immunoglobulin A, immunoglobulin G, and immunoglobulin M levels, and minimized the monocyte ratio [98]. However, insufficient doses may fail to improve immune response [99]. Tamam et al. [100], and Das et al. [101] reported that $C$. verum essential oil promotes macrophages, 
Table-6: List of herbal extract that acts as anti-ectoparasites in poultry.

\begin{tabular}{|c|c|c|c|c|c|}
\hline Plants (species) & Botanical name & Parts used & Mode of action & $\begin{array}{l}\text { Ectoparasites } \\
\text { species }\end{array}$ & References \\
\hline $\begin{array}{l}\text { A. sativum and } C \text {. } \\
\text { verum }\end{array}$ & $\begin{array}{l}\text { Garlic and } \\
\text { cinnamon oil }\end{array}$ & Bulbs and bark & $\begin{array}{l}\text { Eliminate lice and mice } \\
\text { infestations in chickens }\end{array}$ & $\begin{array}{l}\text { Trichomonas, } \\
H . \text { meleagridis, } \\
\text { and head lice }\end{array}$ & [89] \\
\hline $\begin{array}{l}\text { C. deodara, A. indica, } \\
\text { E. ribes }\end{array}$ & Pestoban & Fruit & $\begin{array}{l}\text { Eliminate lice and mice } \\
\text { infestations in chickens }\end{array}$ & $\begin{array}{l}\text { D. gallinae, } \\
\text { Knemidocoptes } \\
\text { mutans }\end{array}$ & {$[90,91]$} \\
\hline A. sativum & Garlic & Bulbs & $\begin{array}{l}\text { Eliminate lice and mice } \\
\text { infestations in chickens }\end{array}$ & D. gallinae & {$[92]$} \\
\hline S. aromaticum & Clove & Flower buds & $\begin{array}{l}\text { Eliminate lice and mice } \\
\text { infestations in chickens }\end{array}$ & L. caponis L. & [93] \\
\hline A. senegalensis & $\begin{array}{l}\text { African } \\
\text { custard- apple }\end{array}$ & Fruit & $\begin{array}{l}\text { Eliminate lice and mice } \\
\text { infestations in chickens }\end{array}$ & D. gallinae & [94] \\
\hline T. grandis & Teak & Flower & & & \\
\hline S. longepedunculata & Violet tree & Leaves & & & \\
\hline I. hirsuta & Hairy indigo & Leaves & & & \\
\hline L. lanceolata & $\begin{array}{l}\text { Dwarf red } \\
\text { ironwood }\end{array}$ & Seeds & & & \\
\hline H. spicigera & Black sesame & Seeds & & & \\
\hline S. araliacea & Apiaceae & Leaves & & & \\
\hline O. abyssinica & (A. Rich) Munro & Seeds & & & \\
\hline N. tabacum & Tobacco & Leaves & & & \\
\hline J. curcas & Jarak pagar & Leaves & & & \\
\hline F. exasperata & Moraceae & Leaves & & & \\
\hline A. indica & Neem & Leaves & & & \\
\hline P. biglobosa & $\begin{array}{l}\text { African locust bean } \\
\text { tree }\end{array}$ & Pods & & & \\
\hline
\end{tabular}

A. indica $=$ Azadirachta indica, $A$. sativum $=$ Allium sativum, $C$. verum $=$ Cinnamomum verum, $H$. meleagridis $=$ Histomonas meleagridis, D. gallinae=Dermanyssus gallinae, L. caponis=Lipeurus caponis, A. senegalensis=Annona

senegalensis, $T$. grandis=Tectona grandis, S. Iongepedunculata=Securidaca longepedunculata, $I$. hirsute=Indigofera hirsute, L. lanceolata=Lophira lanceolata, H. spicigera=Hyptis spicigera, S. araliacea=Steganotaenia araliacea, O. abyssinica=Oxytenanthera abyssinica, N. tabacum=Nicotiana tabacum, J. curcas=Jatropha curcas,

P. biglobosa=Parkia biglobosa, C. deodara=Cedrus deodara, E. ribes=Embelia ribes, S. aromaticum=Syzygium aromaticum, F. exasperata=Ficus exasperata

phagocytosis, and killing of invading microorganisms by macrophages, facilitating the body's primary line of defense against Newcastle disease infection. The table below shows herbs that act as immunomodulators in poultry (Table-7).

\section{Antioxidants}

Adding Borreria latifolia to the chicken diet can help prevent lipid peroxidation [102]. The phenols act to minimize lipid peroxidation and inhibit free radicals and oxidative deterioration, which can improve chicken meat quality. Antioxidant properties have also been observed in broiler chicken meal supplemented with a mixture of bitter leaf meal and $M$. oleifera leaf without affecting serum biochemistry of the experimental birds [103]. Both leaves contain phytochemicals, such as flavonoid, quercetin, and phenol that can increase serum antioxidant enzymes, such as glutathione, catalase, and superoxide dismutases, and decrease lipid peroxidation. A review by Ali et al. [104] also mentioned that cinnamon was safe for poultry health and had positive environmental and economic aspects. Bravo et al. [105] demonstrated increased energy utilization and growth performance in broilers after administering a mixture of cinnamaldehyde, carvacrol, and capsicum oleoresin. The additive effect of plants supports antioxidant enzyme function of the mucosal layer cells that protect the tissue [106], suggesting the potential for plant extracts as antioxidants. The table shows herbs that act as antioxidants for poultry (Table-8).

\section{Body Weight Gain}

Administering medicinal plants in animal production health are increasing following several studies that have highlighted the additive effects of plants in improving biological development. Herbal medicines, such as white turmeric (curcumin), red ginger (zingerone), galangal (methyl-cinnamic), and garlic (allicin), are alternative treatments due to their ability to increase the viability of chickens, as indicated by a decrease in the percentage mortality and body weight gain. These plants improved digestibility and durability of treated chickens, resulting in better nutrient intake [107]. Further, a combination of A. sativum, Urtica dioica, Inula helenium, Glycyrrhiza glabra, $R$. officinalis, Chelidonium majus, Thymus serpyllum, Tanacetum vulgare, and Coriandrum sativum increased chicken weight gain and food conversion ratio in an anti-coccidial study [108]. This formula is rich in polyphenols that reduce the oocyst output and decrease the total lesion score, thereby improving digestibility. Naderi et al. [109] also revealed that adding $2.5 \mathrm{~g}$ of turmeric powder to 
Table-7: List of herbal extract that acts as immunomodulator in poultry.

\begin{tabular}{|c|c|c|c|c|c|}
\hline Plants (species) & $\begin{array}{l}\text { Botanical } \\
\text { name }\end{array}$ & Parts used & Mode of action & Agent & References \\
\hline Capsicum L. & Capsicum & Fruits & $\begin{array}{l}\text { Regression of } \mathrm{CD}_{40} \mathrm{LG}, \mathrm{IFN}-\mathrm{G} \text {, and } \\
\mathrm{IL}-6 \text {, indicating low inflammation, } \\
\text { higher levels of serum antibodies and } \\
\text { enhanced pro-inflammatory cytokine } \\
\text { production in the duodenum }\end{array}$ & $\begin{array}{l}\text { Eimeria } \\
\text { spp. }\end{array}$ & [95] \\
\hline A. membranaceus & Huangqi & Leaves, roots & $\begin{array}{l}\text { Improved immune activity in } \\
\text { broiler chicks infected with } \\
\text { lipopolysaccharide The immune organ } \\
\text { weight and IgG level increased, } \\
\text { while the liver and kidney functions } \\
\text { improved. The plant stimulated the } \\
\text { growth of the fecal microorganism } \\
\text { composition }\end{array}$ & Unspecified & {$[96]$} \\
\hline A. vera & Aloe & Leaves & CARN750 compound stimulate & Unspecified & [97] \\
\hline P. ginseng & $\begin{array}{l}\text { Asian } \\
\text { ginseng }\end{array}$ & $\begin{array}{l}\text { Roots and } \\
\text { leaves }\end{array}$ & $\begin{array}{l}\text { cytokine and lymphocytes, while the } \\
\text { roots and leaves of } P \text {. ginseng rich } \\
\text { in saponin that effectively stimulate } \\
\text { lymphocytes, cytokine, and IL-6, and } \\
\text { improve the work of macrophage. } \\
\text { potential resistance to viral infections } \\
\text { in birds by stimulating macrophage } \\
\text { production as well as T-cell-mediated } \\
\text { immune responses, stimulating } \\
\text { macrophages through TLR6 } \\
\text { signaling and NF-kappa B. Improved } \\
\text { hematological profile }\end{array}$ & & \\
\hline C. longa & Turmeric & $\begin{array}{l}\text { Rhizome } \\
\text { powder }\end{array}$ & $\begin{array}{l}\text { Improved blood IgA, IgG, and IgM } \\
\text { levels, and minimized the monocyte } \\
\text { ratio }\end{array}$ & Unspecified & {$[98,99]$} \\
\hline C. verum & Cinnamon & Barks & $\begin{array}{l}\text { Promotes macrophages, } \\
\text { phagocytosis, and killing of invading } \\
\text { microorganisms by macrophages, } \\
\text { facilitating the body's primary line of } \\
\text { defense against viral infection }\end{array}$ & NDV & {$[100]$} \\
\hline
\end{tabular}

$\mathrm{NDV}=$ Newcastle disease virus, $\mathrm{IL}=$ Interleukin, INF=Interferon $C$. longa=Curcuma longa, $C$. verum=Cinnamomum verum, $A$. membranaceus=Astragalus membranaceus, $P$. ginseng=Panax ginseng, $A$. vera=Aloe vera

Table-8: List of herbal extract that acts as antioxidant in poultry.

\begin{tabular}{|c|c|c|c|c|}
\hline $\begin{array}{l}\text { Plants } \\
\text { (species) }\end{array}$ & $\begin{array}{l}\text { Botanical } \\
\text { name }\end{array}$ & Parts used & Mode of action & Reference \\
\hline B. latifolia & $\begin{array}{l}\text { Broadleaf button } \\
\text { weed }\end{array}$ & Leaves & $\begin{array}{l}\text { The phenols act to minimize lipid } \\
\text { peroxidation to inhibit free radicals and } \\
\text { oxidative deterioration which improves } \\
\text { the chicken meat quality }\end{array}$ & {$[102]$} \\
\hline $\begin{array}{l}\text { V. amygdalina } \\
\text { and M. oleifera }\end{array}$ & $\begin{array}{l}\text { Bitter leaf meal } \\
\text { and drumstick } \\
\text { leaf }\end{array}$ & Leaves & $\begin{array}{l}\text { Contain phytochemicals such as } \\
\text { flavonoid, quercetin, and phenol that } \\
\text { increased serum antioxidant enzymes } \\
\text { such as GSH, catalase, and SOD and } \\
\text { decreased lipid peroxidation }\end{array}$ & {$[103]$} \\
\hline C. verum & Cinnamon & Barks & Support anti-inflammatory effect & {$[104]$} \\
\hline Capsicum L. & Capsicum & Fruits & $\begin{array}{l}\text { Increased energy utilization and growth } \\
\text { performance in broilers } \\
\text { Supports the function of antioxidant } \\
\text { enzymes of the mucosal layer cells that } \\
\text { protect the tissue }\end{array}$ & {$[105,106]$} \\
\hline
\end{tabular}

SOD =Superoxide dismutase, $M$. oleifera=Moringa oleifera, $C$. verum=Cinnamomum verum, $V$. amygdalina=Vernonia amygdalina, $B$. latifolia=Borreria latifolia

$1 \mathrm{~kg}$ poultry feed significantly increased body weight gain during the starter (0-21 days) period. Including $5 \mathrm{~g}$ of $C$. longa powder in a $1 \mathrm{~kg}$ diet also improved growth rates of broilers. Turmeric not only increased the weight of bursa of Fabricius but also promoted the production and secretion of bile and digestive enzymes, thereby improving digestion and absorption of dietary nutrients.

Another herb with the same potential is Allium hookeri root [110], which contains organosulfur compounds, proteins, volatile sulfur, prostaglandins, fructans, vitamins, and polyphenols that improved 
body weight gain after $1 \% A$. hookeri root was administered on treatment day 14 to broilers. Further, $A$. vera polysaccharides administered to chickens infected with Eimeria spp. affected intestinal microflora and reduced intestinal lesions, promoting weight gain, and better performance [111]. Curcumin and turmeric can enhance body weight gain due to their effects on feed intake and improved growth [112]. Dosoky and Setzer [113] showed that curcumin acts as a stimulant, carminative, stimulates digestibility, has antimicrobial properties, and is a gastric toxicity inhibitor, while turmeric (1\%) acts as an antioxidant in promoting positive feed conversion ratio [114].

Moringa stenopetala leaf meal exhibits high pepsin soluble nitrogen (82-91\%), low acid detergent-insoluble protein (1-2\%), and low antinutritional factors [115]. It may also contain Vitamin E [116] to improve intestinal microarchitecture and produce acidic mucin, as shown in treated chickens [117]. Cinnamon and thyme administration in a dose of $0.5 \%$, $1 \%$ thyme, and $1 \%$ cinnamon in chickens with colibacillosis effectively decreased total aerobic bacterial count of the gastrointestinal tract and improved body performance in chickens [118]. These herbs altered cell wall permeability of bacteria and created a pore that leads to osmotic shock and leakage of the cytoplasm, resulting in cell death [119]. Another study showed that nettle or lemon balm can improve chicken body weight after 21 days of administration [120]. Nettle has anti-inflammatory properties and high flavonoid content that relaxes smooth muscles of the digestive tract and bile ducts [121]. It is also rich in antioxidants that act intracellularly [122], which could be responsible for better animal performance. The study also revealed that herbs successfully replaced antibiotic growth promoters; moreover, adding $0.1 \%, 0.25 \%$, and $0.5 \%$ crude preparation of fenugreek, ginger, and turmeric in the diet-stimulated growth rates of gut layers by significantly reducing the excretion of fecal anaerobic bacteria while maintaining excretion of beneficial bacteria [123]. Abdullahi et al. [124] revealed that herbs stimulated the production of IL-2, IL-10, tumor necrosis factor, and IFN- $\gamma$, improving Ig antibody levels in serum, thereby promoting daily weight gain. The table below describes various herbs that improve body weight promoters in poultry (Table-9).

\section{Anticancer}

Recent studies on cancer have bolstered our medical understanding. Cancer occurs not only in humans but also in animals and is frequently described as cellular mutation to DNA within cells because of free radicals in the body affected by exposure to ionizing radiation and other experimental toxins [125]. In avian species, cancer is often related to viruses, namely, avian leukosis virus, Marek's disease virus, reticuloendotheliosis virus, and lymphoproliferative disease viruses [126].

Chemotherapy is considered the sole treatment for cancer. The genes inside the nucleus of cells will be damaged. Some chemotherapeutic drugs operate by splitting cells, while others aim to inhibit the process of gene replication before cell splitting. In some cases, however, chemotherapy can damage healthy cells and release a protein that supports tumor growth [127].

Herbs can be used in various ways to support cancer treatment by relieving the undesirable effects of chemotherapy, accommodating convalescence after chemo- and radio-therapeutics, promoting the conventional cancer treatment, supporting conventional treatment in some conditions, assisting in cancer prevention, strengthening immune function, and promoting various tracts influenced by cancer [128].

Grape seed proanthocyanidin extract is a polyphenolic antioxidant with pharmacological and nutraceutical benefits, including anticancer properties [129]. Proanthocyanidins can scavenge free radicals 20 -fold better than other antioxidants, such as Vitamin C, Vitamin $\mathrm{E}$, and $\beta$-carotene, and have potential as cancer growth inhibitors with significantly greater protection against free radicals, free radical-induced lipid peroxidation, and DNA damage [130]. Moreover, seed grape oil has previously shown antioxidant components and effectively worked as a natural antioxidant in broilers [131].

Natural killer (NK) cells known as innate immune cells can eradicate tumor cells [132] by delivering cytotoxic granules containing perforin and granzymes, which lyse target cells [133]. Ashwagandha (W. somnifera Dunal) may improve NK cell function in ovarian tumor in laying hen model to diminish occurrence and development of ovarian tumor tissue [134]. The plant has cytolytic properties to fight human tumor cell lines $[135,136]$. Other herbs that promote NK cells activity are found within the combination of $W$. somnifera, Glycyrrhiza glabra, Z. officinale, O. sanctum, and Elettaria cardamomum, which can be fortified in regular tea [137].

A formulation of dandelion root, mustard leaf, and safflower leaf can improve innate chicken immunity, including peripheral blood lymphocyte proliferation, nitric oxide production by macrophages, and free radical scavenging activity, as well as prevent chicken tumor cell development [138]. Other studies showed that safflower (Carthamus tinctorius) can augment natural immunity and medicate cancers. Safflower petals contain polysaccharides that augment splenocyte proliferation and stimulate macrophage activation, as well as significantly diminish the viability of chicken tumor cells [139].

Turmeric (C. longa Linn.) contains high levels of antioxidants and anti-inflammatory properties [140]. Daily curcumin intake produces a significant and dose-dependent reduction in spontaneous ovarian cancer occurrence and tumor growth, presenting a recommended chemopreventive strategy for ovarian cancer [141]. Various molecular mechanisms revealed that NF-kB and STAT3 signaling pathways were significantly inhibited. However, the nuclear factor erythroid 2/ 
Table-9: List of herbal extract that acts as body weight promoter in poultry.

\begin{tabular}{lll}
\hline Plants (species) & Botanical name & Parts used \\
\hline C. zedoaria & White turmeric & Rhizomes \\
A. purpurata & Red ginger & Rhizomes \\
K. galanga & Galangal & Rhizomes \\
A. sativum & Garlic & Bulbs \\
A. sativum & Garlic & Bulbs \\
U. dioica & Nettle & Leaves \\
I. helenium & Elecampane & Rhizomes \\
G. glabra & Liquorice & Roots \\
R. officinalis & Rosemary & Leaves \\
C. majus & Greater celandine & Aerial parts and \\
T. serpyllum & & roots \\
T. vulgare & Breckland thyme & Leaves \\
C. sativum & Tansy & \\
C. longa & Coriander & Leaves, aerial parts, \\
& & Seeds, leaves, roots
\end{tabular}

Mode of action
Improved the digestibility and
durability of treated chicken,
resulting in a better intake of
nutrients
The formula is rich in polyphenols
that reduce the oocyst output and
decrease the total lesion score,
thereby improving digestibility
A. hookeri
Garlic chives
Roots
A. vera
Aloe
Leaves

C. longa and

Curcumin and

Rhizomes

C. aromatica

turmeric

Leaves

C. verum and

T. vulgaris

Cinnamon and

thyme

U. dioica

Nettle
Increased the weight of bursa of Fabricius but also promoted the production and secretion of bile and digestive enzyme, thereby improving digestion and the absorption of dietary nutrients The organosulfur compounds, proteins, volatile sulfur compounds, prostaglandins, fructans, vitamins, and polyphenols that improved body weight gain

The polysaccharides affected the intestinal microflora and reduced intestine lesion, promoting weight gain and better performance

Curcumin is a stimulant, carminative, stimulates digestibility, has antimicrobial properties, and is a gastric toxicity inhibitor, while turmeric (1\%) acts as an antioxidant in promoting feed conversion ratio

The bioactive compounds improved the intestinal microarchitecture and the production of acidic mucin Decreased the total aerobic bacteria count of the gastrointestinal tract and improved the body performance of the chicken Nettle has anti-inflammatory properties and high flavonoid content that relaxed smooth muscles of the digestive tract and the bile ducts. It is also rich in antioxidants that act intracellularly that might be responsible for better animal performance Stimulated the growth rate of layers by significantly reduction of excretion of fecal anaerobic bacteria and no changes in excretion of beneficial bacteria. The herbs stimulated the production of IL-2, IL-10, TNF, and IFN- $\gamma$, improving the Ig antibody level in serum, thereby promoting daily weight gain

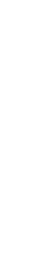

\footnotetext{
TNF=Tumor necrosis factor, IL=Interleukin, INF=Interferon, $C$. longa=Curcuma longa, $A$. sativum=Allium sativum, $R$. officinalis=Rosmarinus officinalis, $T$. vulgaris $=$ Thymus vulgaris, $C$. verum $=$ Cinnamomum verum, U. dioica $=$ Urtica dioica, I. helenium =Inula helenium, C. majus=Chelidonium majus, T. serpyllum=Thymus serpyllum, C. sativum=Coriandrum sativum, A. hookeri=Allium hookeri, M. stenopetala=Moringa stenopetala, Z. officinale=Zingiber officinale, C. zedoaria=Curcuma zedoaria, A. purpurata=Alpinia purpurata, K. galangal=Kaempferia galangal, G. glabra=Glycyrrhiza glabra, $T$. vulgare=Tanacetum vulgare, $A$. vera=Aloe vera, $C$. aromatic=Curcuma aromatic, $T$. foenum=Trigonella foenum
} 
Table-10: List of herbal extract acts as anticancer in poultry.

\begin{tabular}{|c|c|c|c|c|}
\hline Plants (species) & $\begin{array}{l}\text { Botanical } \\
\text { name }\end{array}$ & Parts used & Mode of action & Reference \\
\hline V. vinifera & Grape & Seeds & $\begin{array}{l}\text { Proanthocyanidins are able in scavenging the free } \\
\text { radical, indicated as potential for cancer growth } \\
\text { inhibition and significantly greater protection } \\
\text { against free radicals, free radical-induced lipid } \\
\text { peroxidation and DNA damage. Moreover, seed } \\
\text { grape oil indicated antioxidant substances and } \\
\text { worked effectively as origin of natural antioxidants } \\
\text { to broiler }\end{array}$ & {$[128,129,130]$} \\
\hline $\begin{array}{l}\text { W. somnifera } \\
\text { Dunal }\end{array}$ & Ashwagandha & Roots & $\begin{array}{l}\text { Improves the NK cell function in ovarian tumor } \\
\text { in the laying hen model that diminished the } \\
\text { occurrence and development of ovarian tumor. The } \\
\text { plant has cytolytic effect that applicable against } \\
\text { human tumor cell lines }\end{array}$ & {$[133-135]$} \\
\hline G. glabra & Liquorice & Roots & Promote NK cells activity that are in the & {$[136]$} \\
\hline Z. officinale & Ginger & Rhizomes & combination with $W$. somnifera, that fortified in a & \\
\hline O. sanctum & Tulsi & Leaves & regular tea & \\
\hline E. cardamomum & Cardamom & Fruits & & \\
\hline $\begin{array}{l}\text { Taraxacum F.H } \\
\text { Wigg. }\end{array}$ & Dandelion & Roots & $\begin{array}{l}\text { Affecting chicken innate immunity including } \\
\text { peripheral blood lymphocyte proliferation, nitric }\end{array}$ & {$[137]$} \\
\hline B. juncea & Mustard & Leaves & oxide production by macrophages and free radical & \\
\hline C. tinctorius & Safflower & Leaves & $\begin{array}{l}\text { scavenging activity; and preventing chicken tumor } \\
\text { cell development }\end{array}$ & \\
\hline C. tinctorius & Safflower leaf & Leaves & $\begin{array}{l}\text { Augment natural immunity and medicate cancers. } \\
\text { The safflower petals contain polysaccharides that } \\
\text { augmented splenocyte proliferation and stimulated } \\
\text { macrophages activation, and significantly } \\
\text { diminished the viability of chicken tumor cell }\end{array}$ & [138] \\
\hline C. longa Linn. & Turmeric & Rhizomes & $\begin{array}{l}\text { Contain high of antioxidant and anti-inflammatory } \\
\text { properties } \\
\text { The plant inhibits NF-kB and STAT3 signaling } \\
\text { pathways, however, that the nuclear factor } \\
\text { erythroid } 2 / \text { hemeoxygenase } 1 \text { antioxidant } \\
\text { pathway was stimulated by curcumin intake in a } \\
\text { dose-dependent manner in ovarian tissues }\end{array}$ & $\begin{array}{c}{[139]} \\
{[140,141]}\end{array}$ \\
\hline
\end{tabular}

NK=Natural killer, $W$. somnifera=Withania somnifera, $O$. sanctum=Ocimum sanctum, C. Ionga=Curcuma longa, E. cardamom=Elettaria cardamom, C. tinctorius=Carthamus tinctorius, V. vinifera=Vitis vinifera, G. glabra=Glycyrrhiza glabra, $Z$. officinale=Zingiber officinale, $B$. juncea=Brassica juncea

heme oxygenase 1 antioxidant pathway was stimulated by curcumin intake in a dose-dependent manner in ovarian tissue [141]. A compilation of herbs that have anticancer properties for poultry is shown in Table-10.

\section{Conclusion}

This review demonstrated that certain plants are potential medicines for avian species. Various plants present numerous advantages, including minimal side effects potentially harmless for birds, humans, and the environment, as well as limiting drug resistance and diminishing residue in chicken meat and eggs. Further studies on other medicinal plants applied to chickens are needed to explore the potential of other plants on avian health. In the future, natural products with low side effects to fight poultry disease may be possible; moreover, some possible limitations in this review can exist. More methodological work is needed to offer more medicinal plants as alternatives to synthetic drugs that are effective and safe for poultry, humans, and the environment.

\section{Authors' Contributions}

TH, MRAAS, and RLB: Conceptualized and designed the review. TH and MRAAS: Collected the literatures. TH: Analyzed the data. TH and SJ: Drafted the manuscript. RLB, BPP, and SJ: Edited and finalized the manuscript. All authors read and approved the manuscript.

\section{Acknowledgments}

The study was funded by Padjadjaran University through Riset Disertasi Dosen Universitas Padjadjaran 2019, Indonesia (No. 1427/UN6.3.1/LT/2020).

\section{Competing Interests}

The authors declare that they have no competing interests.

\section{Publisher's Note}

Veterinary World remains neutral with regard to jurisdictional claims in published institutional affiliation.

\section{References}

1. Callens, B., Cargnel, M., Sarrazin, S., Dewulf, J., Hoet, B., Vermeersch, K., Wattiau, P. and Welby, S. (2018) Associations between a decreased veterinary antimicrobial use and resistance in commensal Escherichia coli from Belgian livestock species (2011-2015). Prev. Vet. Med., 
157: 50-58.

2. Agyare, C., Baomah, V.E., Ngofi, C. and Osei, F.B. (2018) Antibiotic Uses in Poultry Production and its Effects on Bacterial Resistance. IntechOpen, London. p34.

3. World Health Organization. (2020) Antimicrobial Resistance. Available from: https://www.who.int/newsroom/fact-sheets/detail/antimicrobial-resistance Retrieved on 28-05-2021.

4. World Health Organization. (2017) Critically Important Antimicrobials for Human Medicine, $5^{\text {th }}$ Revision. Available from: http://www.who.int/foodsafety/publications/antimicrobials-fifth/en/googlescholar Retrieved on 28-05-2021.

5. World Health Organization. (2019) WHO Global Report on Traditional and Complementary Medicine. Available from: https://www.who.int/traditional-complementary-integrativemedicine/Whoglobalreporton traditional and complementary medicine2019.pdf?ua=1 Retrieved on 28-05-2021.

6. Liu, Q., Meng, X., Li, Y., Zhao, C.N., Tang, G.Y. and Li, H.B. (2017) Antibacterial and antifungal activities of spices. Int. J. Mol. Sci., 18(6): 1283.

7. Chhabra, M.B., Pathak, K.M.L. and Muraleedharan, K. (2014) Medicinal plants as an alternative for control of livestock parasites. 2. Protozoa. Indian J. Anim. Res., 84(6): 599-608.

8. Pop, L.M., Varga, E., Coroian, M., Nedisan, M.E., Mircean, V., Dumitrache, M.O., Farczádi, L., Fülöp, I., Croitoru, M.D., Fazakas, M. and Györke, A. (2019) Efficacy of a commercial herbal formula in chicken experimental coccidiosis. Parasit. Vectors, 12(1): 343.

9. Gado, A.R., Ellakany, H.F., Elbestawy, A.R., Abd El-Hack, M.E., Khafaga, A.F., Taha, A.E., Arif, M. and Mahgoub, S.A. (2019) Herbal medicine additives as powerful agents to control and prevent avian influenza virus in poultry. Ann. Anim. Sci., 19(4): 905-935.

10. Haniarti, H., Munir, M., Akib, M.A., Ambar, A., Rusman, A.D.P. and Abdullah, A. (2019) Herbal for Increasing Immunity and Weight of Poultry. $1^{\text {st }}$ International Conference of Animal Science and Technology (ICAST) 2018. IOP Conference Series: Earth and Environmental Science. p1-7.

11. Cowan, M.M. (1999) Plant products as antimicrobial agents. Clin. Microbiol. Rev., 12(4): 564-582.

12. Mapiye, C., Mwale, M., Mupangwa, J.F., Chimonyo, M., Foti, R. and Mutenje, M.J. (2008) A research review of village chicken production constraints and opportunities in Zimbabwe. Asian Australas. J. Anim. Sci., 21(11): 1680-1688.

13. Zhai, L., Li, Y., Wang, W. and Hu, S. (2011) Enhancement of humoral immune responses to inactivated Newcastle disease and avian influenza vaccines by oral administration of ginseng stem-and-leaf saponins in chickens. Poult. Sci., 90(9): 1955-1959.

14. Food and Agriculture Organization. (2009) A Review of the Current Poultry Disease Control Strategies in Smallholder Poultry Production Systems and Local Poultry Populations in Uganda. Available from: http://www.fao.org/3/al687e/ al687e00.pdf Retrieved on 28-05-2021.

15. Yasmin, A.R., Chia, S.L., Looi, Q.H., Omar, A.R., Noordin, M.M. and Ideris, A. (2020) Herbal extracts as antiviral agents. In: Panagiota Florou-Paneri, Efterpi Christaki, Ilias Giannenas, editor. Feed Additives Aromatic Plants and Herbs in Animal Nutrition and Health. $1^{\text {st }}$ edition. Cambridge: Academic Prints. 115-132.

16. Ou, C., Shi, N., Pan, Q., Tian, D., Zeng, W. and He, C. (2013) Therapeutic efficacy of the combined extract of herbal medicine against infectious bursal disease in chickens. Pak. Vet. J.,33(3): 304-308.

17. Mahal, A., Duan, M., Zinad, D.S., Mohapatra, R.K., Obaidullah, A.J., Wei, X., Pradhan, M.K., Das, D., Kandi, V., Zinad, H.S. and Zhu, Q. (2021) Recent progress in chemical approaches for the development of novel neuraminidase inhibitors. R. Soc. Chem. Adv., 11(3): 1804-1840.
18. Aslam, A., Mahmood, M.S., Hussain, H. and Khan, N. (2014) Evaluation of antiviral effect of epigallocatechin gallate, epigallocatechin, epicatechin gallate and green tea extract against fowl adenovirus-4. Pak. J. Zool., 46(5): 1283-1294.

19. Mady, W., Arafa, A., Hussein, A.S., Aly, M.M. and Madbouly, H. (2013) Nigella sativa oil as an immunostimulant adjuvant in $\mathrm{H} 5$ based DNA vaccine of $\mathrm{H} 5 \mathrm{~N} 1$ avian influenza virus. Glob. Vet., 10(6): 663-668.

20. Li, L.J., Ming, Y.L., Li, Y.T., Feng, J.J., Hao, F.Q. and Zhang, L. (2012) Adjuvant activity of Sargassum pallidum polysaccharides against combined Newcastle disease, infectious bronchitis, and avian influenza inactivated vaccines. Marine Drugs, 10(12): 2648-2660.

21. Yuniwarti, Y.W.E., Asmara, W., Artama, W. and Tabbu, R.C. (2012) The effect of virgin coconut oil on lymphocyte and cd4 in chicken vaccinated against avian influenza virus. $J$. Indones. Trop. Anim. Agric., 37(1): 64-69.

22. Vilhelmova-Ilieva, N., Galabov, A.S. and Mileva, M. (2019) Tannins as Antiviral Agent. Available from: https://www. intechopen.com/books/tannins-structural-properties-biological-properties-and-current-knowledge/tannins-as-antiviral-agents Retrieved on 28-05-2021

23. Latheef, S.K., Dhama, K., Samad, H.A., Wani, M.Y., Kumar, M.A., Palanivelu, M., Malik, Y.S., Singh, S.D. and Singh, R. (2017) Immunomodulatory and prophylactic efficacy of herbal extracts against experimentally induced chicken infectious anemia in chicks: Assessing the viral load and cell-mediated immunity. Virusdisease, 28(1): 115-120.

24. Eladl, A.H., Mosad, S.M., El-Shafei, R.A., Saleh, R.M., Ali, H.S., Badawy, B.M. and Elshal, M.F. (2020) Immunostimulant effect of a herbal extract on infectious bursal disease virus (IBDV) vaccinated chickens in the context of a co-infection model of avian influenza virus H9N2 and IBDV. Comp. Immunol. Microbiol. Infect. Dis., 72(1): 101505.

25. Rose, K., Wan, C., Thomas, A., Seeram, N.P. and Ma, H. (2018) Phenolic compounds isolated and identified from amla (Phyllanthus emblica) juice powder and their antioxidant and neuroprotective activities. Nat. Prod. Commun., 13(10): 1309-1311.

26. Ram, M., Neetu, D., Deepti, P., Vandana, M., Ilavazhagan, G. and Kumar, D. (2001) Cytoprotective activity of amla (Emblica officinalis) against chromium (VI) induced oxidative injury in murine macrophages. Phytother. Res., 17(4): 430-433.

27. Dalal, R., Ahlawat, P.K., Sonu, Vinus, Panwar, V.S., Tewatia, B.S. and Sheoran, N. (2018) Evaluation of antimicrobial effects of Emblica officinalis fruit powder on intestinal microbiota in broilers chicken. Int. J. Curr. Microbiol. App. Sci., 7(4): 1432-1438.

28. Norouzi, B., Qotbi, A.A.A., Seidavi, A., Schiavone, A. and Marin, A.L.M. (2015) Effect of Different dietary levels of rosemary (Rosmarinus officinalis) and yarrow (Achillea millefolium) on the growth performance, carcass traits, and ileal microbiota of broilers. Ital. J. Anim. Sci., 14(3): 448-453.

29. Hanan, E.A. (2014) Effect of different levels of turmeric (Curcuma longa) supplementation on broiler performance, carcass characteristics and bacteria count. Egypt. J. Poult. Sci., 35(1): 25-39.

30. Lannaon, W.J. (2010) Herbal Trees Used as Antibiotics for Broilers. Poultry World. Available from: https://www.poultryworld.net/health/articles/2016/5/herbal-trees-used-asantibiotics-for-broilers-2807282W Retrieved on 28-05-2021.

31. Mapatac, L.C. (2018) Potency of medicinal plants in the growth performance in broiler chicks. Recoletos Multidiscip. Res. J., p197-206.

32. Ogundare, A.O. and Oladejo, B.O. (2014) Antibacterial activities of the leaf and bark extract of Persea americana. Am. J. Ethnomed., 1(1): 64-71. 
33. Guzmán-Rodríguez, J.J., López-Gómez, R., SuárezRodríguez, L.M., Salgado-Garciglia, R., RodríguezZapata, L.C., Ochoa-Zarzosa, A. and López-Meza, J. (2013) Antibacterial activity of Defensin PaDef from avocado fruit (Parsea amreicana var. drymifolia) expressed in endothelial cells against Escherichia coli and Staphylococcus aureus. Biomed. Res. Int., 2013(Special issue): 986273.

34. Cardoso, P.F., Scarpassa, J.A., Pretto-Giordano, L.G., Otaguiri, E.S., Yamada-Ogatta, S.F., Nakazato, G., Perugini, M.R.E. and Vilas-Bôas, G.T. (2016) Antibacterial activity of avocado extract (Persea americana Mill) against Staphylococcus agalactiae. YTON, 85(1): 218-224.

35. Ibrahin, S.A., Yang, G., Song, D. and Tse, T.S.F. (2011) Antimicrobial effect of guava on Escherichia coli O157:H7 and Salmonella Typhimurium in liquid medium. Int. J. Food. Prop., 14(1): 102-109.

36. Sharma, Y., Mehrotra, A., Kundu, N. and Srivastava, N. (2018) A study of antibacterial, antioxidant and neuroprotective effect of stem of Syzygium cumini. Int. J. Green. Pharm., 10(4): 236-243.

37. Sallam, S.M.A., Bueno, I.C.S., Brigide, P., Godoy, P.B., Vitti, D.M.S. and Abdalla, A.L. (2009) Efficacy of eucalyptus oil on in vitro ruminal fermentation and methaneproduction. Options Mediterr., 85: 267-272.

38. Daniyan, S.Y. and Muhammad, H.B. (2008) Evaluation of antimicrobial activities and phytochemical properties of extracts of Tamaridus indica against some diseases causing bacteria. Afr. J. Biotechnol., 7(14): 2451-2453.

39. Marino, M., Bersani, C. and Comi, G. (1999) Antimicrobial activity of the essential oils of Thymus vulgaris L. measured using a bioimpedometric method. J. Food Prot., 62(9): 1017-1023.

40. Aktug, S.E. and Karapinar, M. (1986) Sensitivity of some common food poisoning bacteria to thyme, mint, and bay leaves. Int. J. Food Microbiol., 3(6): 349-354.

41. El-Hack, M.E.A., Algawany, M., Abdel-Moneim, A.M.E., Mohammed, N.G., Khafaga, A.F., Bin-Jumah, M., Othman, S.I., Allam, A.A. and Elnesr, S.S. (2020) Cinnamon (Cinnamomum zeylanicum) oil as a potential alternative to antibiotics in poultry. Antibiotics, 9(5): 210.

42. Gupta, C., Garg, A.P., Uniyal, R.C. and Kumari, A. (2008) Comparative analysis of the antimicrobial activity of cinnamon oil and cinnamon extract on some foodborne microbes. Afr. J. Microbiol. Res., 2(9): 247-251.

43. Griggs, J.P. and Jacob J.P. (2005) Alternatives to antibiotics for organic poultry production. J. Appl. Poult. Res., 14(4): 750-756.

44. Ziarlarimi, A., Irani, M., Gharahveisy, S. and Rahmani, Z. (2011) Investigation of antibacterial effects of garlic (Alium sativum), mint (Menthe spp.) and onion (Allium cepa) herbal extracts on Escherichia coli isolated from broiler chicken. Afr. J. Biotechnol., 10(50): 10320-10322.

45. Tell, L.A., Burco, J.D., Woods, L. and Clemons, K.V. (2019) Aspergillosis in Birds and Mammals: Considerations for Veterinary Medicine. Recent Developments in Fungal Diseases of Laboratory Animals. Springer Link, Berlin, Heidelberg. p49-72.

46. Silva, B., Souza, M.M. and Badiale-Furlong, E. (2020) Antioxidant and antifungal activity of phenolic compounds and their relation to aflatoxin B1 occurrence in soybeans (Glycine max L.). J. Sci. Food Agric., 100(3): 1256-1264.

47. Huat, S.S.T., Baker, J.L. and Flores-Espiritu, M. (1999) Interactions of saprophytic yeasts with a nor mutant of Aspergillus flavus. Appl. Environ. Microbiol., 65(6): 2738-2740.

48. Kim, M., Lee, J.H., Koh, H., Lee, S.Y., Jang, C., Chung, C.J., Sung, J.H., Blenis, J. and Chung, J. (2006) Inhibition of ERK-MAP kinase signalling by RSK during Drosophila development. EMBO J., 25(13): 3056-3067.

49. Njoki, L.M., Okoth, S.A. and Wachira, P.M. (2017) Effects of medicinal plant extracts and photosensitization on aflatoxin producing Aspergillus flavus (Raper and Fennell). Int. J. Microbiol., 2017: 5273893.

50. Tajehmiri, A., Rahmani, M.R., Moosavi, S.S., Davari, K. and Ebrahimi, S.S. (2018) Antifungal effects of six herbal extracts against Aspergillus spp. and compared to amphotericin B and nystatin. Int. J. Adv. Appl. Sci., 5(7): 53-57.

51. Amjad, L., Mousavidehmourdi, K. and Rezvani, Z. (2014) In vitro study on antifungal activity of Achillea wilhelmsii flower essential oil against twenty strains of Candida albicans. Chiang Mai J. Sci., 41(51): 1058-1064.

52. Dellavalle, P.D., Cabrera, A., Alem, D., Larrañaga, P., Ferreira, F. and Rizza, M.D. (2011) Antifungal activity of medicinal plant extracts against phytopathogenic fungus Alternaria spp. Chil. J. Agric. Res., 71(2): 231-239.

53. Morissey, J.P. and Osbourne, A. (1999) Fungal resistance to plant antibiotics as a mechanism of pathogenesis. Microbiol. Mol. Biol. Rev., 63(3): 708-724.

54. Selitrennikoff, C.P. (2001) Antifungal proteins. Appl. Environ. Microbiol., 67(7): 2883-2894.

55. Broekaert, W.F., Cammue, B.P.A., De Bolle, M.F.C., Thevissen, K., De Samblanx, G.W. and Osborn, R.W. (1997) Antimicrobial peptides from plants. Crit. Rev. Plant. Sci., 16:297-323.

56. Alizadeh, A., Zamani, E., Sharaifi, R., Javan-Nikkhah, M. and Nazari, S. (2010) Antifungal activity of some essential oils against toxigenic Aspergillus species. Commun. Agric. Appl. Biol. Sci., 75(4): 761-767.

57. Pirbalouti, A.G., Bahmani, M. and Avijgan, M. (2009) Anticandida activity of some of the Iranian medicinal plants. Electron. J. Biol., 5(4): 85-88.

58. Khan, R., Zakir, M., Afaq, S.H., Latif, A. and Khan, A.U. (2010) Activity of solvent extracts of Prosopis spicigera, Zingiber officinale and Trachyspermum ammi against multidrug-resistant bacterial and fungal strains. J. Infect. Dev. Ctries., 4(5): 292-300.

59. Witkowska, D., Sowińska, J., Żebrowska, J.P. and Mituniewicz, E. (2016) The antifungal properties of peppermint and thyme essential oils misted in broiler houses. Rev. Bras. Cienc. Avic., 18(4): 629-637.

60. Abed, A.A., Radwan, I.A.H., El Aziz, M.M.A. and Ali, A. (2021) Antifungal activity of natural essential oils against mold and yeasts associated with respiratory problems in broiler chicken. Adv. Anim. Vet. Sci., 9(3): 348-355.

61. Matrood, A.A.M. and Rhouma, A. (2021) Penicillium and Aspergillus species characterization: Adaptation to environmental factors and sensitivity to aqueous medicinal plants extracts. Rev. Plant. Stud., 8(1): 1-11.

62. Metiner, K., Özkan, O. and AK, S. (2016) In vitro antibacterial and antifungal activity of ethanolic Allium tuncelianum extract. Glob. Vet., 16(1): 26-30.

63. Al-zibaidi, L.A., Wsain, S.M. and Ibrahim, S.M. (2021) Evaluate the antifungal and detoxification of silver nanoparticles prepared with Curcuma plant extract against aflatoxin B1 in broiler feed. IOP Conf. Ser. Earth Environ. Sci., 779: 012076.

64. Habibi, H., Firouzi, S., Nili, H., Razavi, M., Asadi, S.L. and Daneshi, S. (2016) Anticoccidial effects of herbal extracts on Eimeria tenella infection in broiler chickens: In vitro and in vivo study. J. Parasit. Dis., 40(2): 401-407.

65. Muthamilselvan, T., Kuo, T.F., Wu, Y.C. and Yang, W.C. (2016) Herbal remedies for coccidiosis control: A review of plants, compounds, and anticoccidial actions. Evid. Based Complement. Altern. Med., 2016: 2657981.

66. de Almeida, G.E., Horsted, K., Thamsborg, S.M., Kyvsgaard, N.C., Ferreira, J.F.S. and Hermansen, J.E. (2012) Use of Artemisia annua as a natural coccidiostat in free-range broilers and its effects on infection dynamics and performances. Vet. Parasitol., 186(3-4): 178-187.

67. Molan, A.L., Liu, Z. and De, S. (2009) Effect of pine bark (Pinus radiata) extracts on sporulation of coccidian oocysts. FOLIA Parasitol., 56(1): 1-5.

68. Molan, A.L. and Faraj, A.M. (2015) Effect of selenium-rich 
green tea extract on the course of sporulation of Eimeria oocysts. J. Dent. Med. Sci., 14(4): 68-74.

69. Alnassan, A.A., Thabet, A., Daugschies, A. and Bangoura, B. (2015) In vitro efficacy of allicin in chicken Eimeria tenella sporozoites. Parasitol. Res., 114(10): 3913-3915.

70. Allen, P.C. (1997) Nitric oxide production during Eimeria tenella infections in chickens. Poult. Sci., 76(6): 810-813.

71. Nweze, N.E. and Obiwulu, I.S. (2009) Anticoccidial effects of Ageratum conyzoides. J. Ethnopharmacol., 122(1): 6-9.

72. Al-Fifi, Z. (2007) Effects of leaves extract of Carica papaya, Vernonia amigdalina and Azadiratcha indica on the coccidiosis in free-range chickens. Asian J. Anim. Sci., 1(1): 26-32.

73. Nghonjuyi, N.W. (2015) Efficacy of ethanolic extract of Carica papaya leaves as a substitute of sulphonamide for the control of coccidiosis in KABIR chickens in Cameroon. J. Anim. Health Prod., 3(1): 21-27.

74. Hassan, S.M., El-Gayar, A.K., Cadwell, D.J., Bailey, C.A. and Cartwright, A.I. (2008) Guar meal ameliorates Eimeria tenella infection in broiler chicks. Vet. Parasitol., 157(1-2): 133-138.

75. Bozkurt, M., Giannenas, I., Küçükyilmaz, K., Christaki, E. and Florou-Paneri, P. (2013) An update on approach to controlling Coccidia in poultry using botanical extracts. $\mathrm{Br}$. Poult. Sci., 54(6): 713-727.

76. Christaki, E., Florou-Paneri, P., Giannenas, I., Papazahariadou, M., Botsoglou, N. and Spais, A. (2004) Effect of a mixture of herbal extracts on broiler chickens infected with Eimeria tenella. Anim. Res., 53(2): 137-144.

77. Gefu, J.O., Abdu, P.A. and Alawa, C.B. (2000) Ethnoveterinary Practices, Research and Development. Proceedings of the International Workshop on Ethnoveterinary Practices, Kaduna, Nigeria in 2000. National Animal Production Research Institute, Ahmadu Bello University, Zaria, Nigeria.

78. Saleheen, D., Ali, S.A. and Yasinzai, M.M. (2004) Antileishmanial activity of aqueous onion extract in vitro. Fitoterapia, 75(1): 9-13.

79. Durrani, H., Durrani, A. and Kamal, N. (2010) Comparative efficacy of different therapeutic agents in experimentally induced leishmaniasis in hamster. J. Plant Sci., 20(1): 13-16.

80. Hafez, H.M. and Hauck, R. (2006) Efficacy of herbal product against Histomonas meleagridis after experimental infection of turkey poults. Arch. Anim. Nutr., 60(5): 436-442.

81. Hajati, H., Hassanabadi, A. and Ahmadian, F. (2014) Application of medicinal plants in poultry nutrition. J. Med. Plants Prod., 31(1): 1-12.

82. Acorda, J.A., Mangubat I.Y.E. Divina, B.P. (2019) Evaluation of the in vivo efficacy of pumpkin (Cucurbita реро) seeds against gastrointestinal helminths of chicken. Turk. J. Vet. Anim. Sci., 43(2): 206-211.

83. Attia, R.A.H., Mahmoud, A.E., Farrag, H.M.M., Makboul, R., Mohammed, M.E. and Ibraheim, Z. (2015) Effect of myrrh and thyme on Trichinella spiralis enteral and parenteral phases with inducible nitric oxide expression in mice. Mem. Inst. Oswaldo Cruz., 110(8): 1035-1041.

84. Abu, N.E.E. (2005) Effect of Nigella sativa and Allium cepa oils on Trichinella spiralis in experimentally infected rats. J. Egypt. Soc. Parasitol., 35(2): 511-523.

85. Zenner, L., Callait, M.P., Granier, C. and Chauve. C. (2003) In vitro effect of essential oils from Cinnamomum aromaticum, Citrus limon and Allium sativum on two intestinal flagellates of poultry, Tetratrichomonas gallinarum and Histomanas meleagridis. Parasite, 10(2): 153-157.

86. Mueller-Harvey, I. (2006) Unravelling the conundrum of tannins in animal nutrition and health. J. Sci. Food Agric., 86(13): 2010-2037.

87. Siamba, D.N., Okitoi, L.O., Watai, M.K., Wachira, A.M., Lukibisi, F.B. and Mukisira, E.A. (2007) Efficacy of Tephrosia vogelli and Vernonia amrygdalina as anthelmintics against Ascaridia galli in Indigenous chicken. Livest.
Res. Rural Dev., 19(12): 125-128.

88. Islam, K.R., Farjana, T., Begum, N. and Mondal, M.M.H. (2008) In vitro efficacy of some indigenous plants on the inhibition of development of eggs of Ascaridia galli (Digenia: Nematoda). Bangladesh J. Vet. Med., 6(2): 159-167.

89. Jacob, J. and Pescatore, T. (2011) Natural Remedies for Poultry Diseases Common in Natural and Organic Flocks. Land Grant Programs, University of Kentucky, College of Agriculture, Lexington.

90. Ahmed, J. (1986) Use of pestoban for the control of lice in poultry. Int. J. Indig. Med., 5: 11-13.

91. Sinha, R.P., Prasad, R.S., Roy, S. and Zahinuddin, M. (1989) Effect of pestoban against ectoparasites of livestock and poultry. Livest. Advis., 12:26-30.

92. Gorji, S.F., Gorsji, S.F. and Rajabloo, M. (2014) The field efficacy of garlic extracts against Dermanyssus gallinae in layer farms of Babol, Iran. Parasitol. Res., 113(3): 3-6.

93. Pumnuan, J., Insung, A. and Klompanya, A. (2019) Effects of seven plant essential oils on mortalities of chicken lice (Lipeurus caponis L.) adult. Curr. J. Appl. Sci. Technol., 20(1): $52-58$

94. Salifou, S., Offoumon, O.T.L., Gouissi, F.M. and Pangui, L.J. (2013) Endogenous recipes for controlling arthropod ectoparasites of domestic poultry. Rev. Bras. Parasitol. Vet., 22(1): 119-123.

95. Pirgozliev, V., Mansbridge, S.C., Rose, P. and Bravo, D. (2018) Plant extracts, energy, and immune modulation in broilers. In: Phytochemicals-Source of Antioxidants and Role in Disease Prevention. IntechOpen, London. p1024.

96. Farag, M.R. and Alagawany, M. (2019) The role of Astragalus membranaceus as immunomodulator in poultry. Worlds Poult. Sci. J., 75(1): 43-54.

97. Tan, B.K. and Vanitha, J. (2004) Immunomodulatory and antimicrobial effects of some traditional Chinese medicinal herbs: A review. Curr. Med. Chem., 11(11): 1423-1430.

98. Emadi, M., Kermanshahi, H. and Maroufyan, E. (2007) Effect of varying levels of turmeric rhizome powder on some blood parameters of broiler chickens fed corn-soybean meal based diets. Int. J. Poult. Sci., 6(5): 345-348.

99. Nouzarian, R., Tabeidian, S.A., Toghyani, M., Ghalamkari, G. and Toghyani, M. (2011) Effect of turmeric powder on performance, carcass traits, humoral immune responses, and serum metabolites in broiler chickens. $J$. Anim. Feed Sci., 20(3): 389-400.

100. Tamam, S.M., Abdel-Hamid, M.S., Helmy, A.M. and Nakhriry, M. (2017) The antiviral and immunomodulatory activity of Cinnamon zeylanicum "NDV" Newcastle disease virus in chickens. Int. J. Sci. Basic Appl. Res., 32(2): 251-262.

101. Das, D., Roul, A.K., Muduli, S., Nath, S. and Sabat, G.P. (2020) Immunomodulation in poultry. Pharm. Innov., 9(9): 467-472.

102. Abbood, A.A., Kassim, A.B., Jawad, H.A.S., Manap, Y.A. and Sazili, A.Q. (2017) Effects of feeding the herb Borreria latifolia on the meat quality of village chicken in Malaysia. Poult. Sci. J., 96(6): 1767-1782.

103. Daramola, O.T. (2019) Medicinal plants leaf meal supplementation in broiler chicken diet: Effects on performance characteristics, serum metabolite and antioxidant status. Anim. Res. Int., 16(2): 3334-3342.

104. Ali, A., Ponnampalam, E.N., Pushpakumara, G., Cottrell, J.J., Suleria, H.A.R. and Dunshea F.R. (2021) Cinnamon: A natural feed additive for poultry health and production a review. Animals, 11(7): 2026

105. Bravo, D., Pirgozliev, V. and Rose, S.P. (2014) A mixture of carvacrol, cinnamaldehyde, and capsicum oleoresin improves energy utilization and growth performance of broiler chickens fed maize-based diet. J. Anim. Sci., 92(4): 1531-1536.

106. Dhuley, J.N. (1999) Antioxidant effects of cinnamon (Cinnamomum verum) bark and greater cardamom 
(Amomum subulatum) seeds in rats fed a high fat diet. Indian J. Exp. Biol., 37(3): 238-242.

107. Tajeda, O.J. and Kim, W.K. (2021) Role of dietary fibre in poultry nutrition. Animals, 11(2):461.

108. Tsiouris, V., Gianennas, I., Bonos, E., Papadopoulos, E., Stylianaki, J., Sidiropoulou, E., LAzari, D., Tzora, A., Ganguly, B. and Georgopoulou, I. (2021) Efficacy of a dietary polyherbal formula on the performance and gut health in broiler chicks after experimental infection with Eimeria spp. Pathogens, 10(5): 524.

109. Naderi, M., Akbari, M.R., Asadi-Khoshoei, E., Khaksar, K. and Khajali, F. (2014) Effects of dietary inclusion of turmeric (Curcuma longa) and cinnamon (Cinnamomum verum) powders on performance, organs relative weight and some immune system parameters in broiler chickens. Poult. Sci. J., 2(2): 153-163.

110. Einstein-Curtis, A. (2018) Traditional Herb Provides Broilers Non-medicated Performance Boost: Study. Available from: https:/www.feednavigator.com/ Article/2018/06/27/Traditional-herb-provides-broilersnon-medicated-performance-boost-study Retrieved on 28-05-2021.

111. Khaliq, K., Akhtar, M., Awais, M.M. and Anwar, M.I. (2017) Evaluation of immunotherapeutic effects of Aloe vera polysaccharides against coccidiosis in chicken. Kafkas Univ. Vet. Fak. Derg., 23(6): 895-901.

112. Al-Kassie, G., Mohseen, A.M. and Abd-Al-Jaleel, R.A. (2011) Modification of productive performance and physiological aspects of broilers on the addition of a mixture of cumin and turmeric to the diet. Res. Opin. Anim. Vet. Sci., $1(1): 31-34$.

113. Dosoky, N.S. and Setzer, W.N. (2018) Chemical composition and biological activities of essential oils of Curcuma species. Nutrients, 10(9): 1-42.

114. Osman, A.H., El-Far, A.H., Sadek, K.M., Abo-Ghanema, I.I. and Abdel-Latif, M.A. (2017) Immunity, antioxidant status, and performance of broiler chickens fed turmeric (Curcuma longa) rhizome powder. Alex. J. Vet. Sci., 54(2): 19-28.

115. Makkar, H.P.S. and Becker, K. (1997) Nutrients and antiquality factors in different morphological parts of the Moringa oleifera tree. J. Agric. Sci., 128(3): 311-322.

116. Kim, Y.J. and Kim, H.S. (2019) Screening Moringa species focused on development of locally available sustainable nutritional supplements. Nutr. Res. Pract., 13(6): 529-534.

117. Khan, I., Zaneb, H., Yousaf, M.S., Rehman, H.F. and Rehman, H. (2017) Effect of Moringa oleifera leaf powder supplementation on growth performance and intestinal morphology in broiler chicken. J. Anim. Physiol Anim. Nutr., 101(Suppl 1): 114-121.

118. Al-Kassie, G.A. (2009) Influence of two plant extracts derived from Thyme and Cinnamon on broiler performance. Pak. Vet. J., 29(4): 169-173.

119. Lee, K.W., Everts, H., Kappert, H.J., Wouterse, H., Frehner, M. and Beynen, A.C. (2004) Cinnamanaldehyde, but not thymol, counteracts the carboxymethyl cellulose-induced growth depression in female broiler chickens. Int. J. Poult. Sci., 3(9): 608-612.

120. Kwiecieñ, M. and Winiarska-Mieczan, A. (2009) Effect of addition of herbs on body weight and assessment of physical and chemical alterations in the tibia bones of broiler chickens. J. Elem., 14(4): 705-715.

121. Jamroz, D., Wertelecki, T., Houszka, M. and Kamel, C. (2006) Influence of diet type on the inclusion of plant origin active substances on morphological and histochemical characteristics of the stomach and jejunum walls in chicken. $J$. Anim. Physiol. Anim. Nutr., 90(5-6): 255-268.

122. Botsoglou, N.A., Christaki, E., Florou-Paneri, P., Giannenas, I., Papageorgiou, G. and Spais, A.B. (2004) The effect of a mixture of herbal essential oils or L-tocopheryl acetate on performance parameters and oxidation of body lipid in broilers. S. Afr. J. Anim. Sci., 34(1): 52-61.

123. Kalaiselvi, G., Priya, M.S., Puniyamurthy, N. and
Sukumar, K. (2017) Effect of certain herbs on fecal excretion of anaerobic bacteria in layer chicken. Asian J. Sci. Technol., 8(12): 6996-6999.

124. Abdullahi, A.Y., Kallon, S., Yu, I., Zhang, Y. and Li, G. (2016) Vaccination with astragalus and ginseng polysaccharides improves immune response of chickens against H5N1 avian influenza virus. Biomed. Res. Int., 2016: 1510264

125. Valko, M., Leibfritz, D., Moncol, J., Cronin, M.T.D., Mazur, M. and Telser, J. (2007) Free radicals and antioxidants in normal physiological functions and human disease. Int. J. Biochem. Cell Biol., 39(1): 44-84.

126. Witter, R.L. (1997) Avian tumor viruses: Persistent and evolving pathogens. Acta Vet. Hung., 45(3): 251-266.

127. Cancer Research UK. (2020) How Chemotherapy Works. Available from: https://www.cancerresearchuk.org/ about-cancer/cancer-in-general/treatment/chemotherapy/ how-chemotherapy-works Retrieved on 21-05-2021.

128. Qi, F., Li, A., Inagaki, Y., Gao, J., Li, J., Kokudo, N., Li, X.K. and Tang, W. (2010) Chinese herbal medicines as adjuvant treatment during chemo-and radio-therapy for cancer. Biosci. Trends, 4(6): 297-307.

129. Cos, P., De-Bruyne, N., Hermans, S., Apers, D., Berghe, V. and Vlietink, A.J. (2003) Proanthocyanidins in health care current and new trends. Curr. Med. Chem., 11(10): 1345-1359.

130. Bagchi, D., Bagchi, M., Stohs, S.J., Kas, D.K., Ray, S.D., Kuszynski, C.A., Joshi, S.S. and Pruess, H.G. (2000) Free radical and grape seed proanthocyanidin extract: Importance in human health and disease prevention. Toxicology, 148(2-3): 187-197.

131. Turcu, R.P., Panaite, T.D., Untea, A.E., Valice, P.A., Badea, I.A. and Mironeasa, S. (2011) Effects of grape seed oil supplementations to broilers diets on growth performance, meet fatty acids, health lipid indices and lipid oxidation parameters. Agriculture, 11(5): 404.

132. Hu, W., Wang, G., Huang, D., Sui, M. and Xu, Y. (2019) Cancer immunotherapy based on natural killer cells: Current progress and new opportunities. Front. Immunol., 10: 1205 .

133. Krzewski, K. and Coligan, J.E. (2012) Human NK cell lytic granules and regulation of their exocytosis. Front. Immunol., 3: 335.

134. Barua, A., Bradaric, M.J., Bitterman, P., Abramowicz, J., Sharma, S., Basu, S., Lopez, H. and Bhar, M. (2013) Dietary supplementation of Ashwagandha (Withania somnifera, Dunal) enhances NK cell function in ovarian tumors in the laying hen model of spontaneous ovarian cancer. $\mathrm{Am}$. J. Reprod. Immunol., 70(6): 538-550.

135. Hsieh, P.W., Huang, Z.Y, Chen, J.H, Chang, F.R., Wu, C.C., Yang, Y.L., Chiang, M.Y., Yen, M.H., Chen, S.L., Yen, H.F., Lubken, T., Hung, W.C. and Wu, Y.C. (2007) Cytotoxic withanolides from Tubocapsicum anomalum. J. Nat. Prod., 70(5): 747-753.

136. Abdeljebbar, L.H., Benjouad, A., Morjani, H., Merghoub, N., El Haddar, S., Humam, M, Christen, P., Hostettmann, K., Bekkouche, K. and Amzazi, S. (2009) Antiproloferative effects of withanolides from Withania adpressa. Thérapie, 64(2): 121-127.

137. Bhat, J., Damle, A., Vaishnav, P.P., Albers, R., Joshi, M. and Banerjee. G. (2010) In vivo enhancement of natural killed cell activity through tea fortified with Ayurvedic herbs. Phytother. Res., 24(1): 129-135.

138. Lee, S.H., Lillehoj, H.S., Chun, H.K., Tuo, W., Park, H.J., Cho, S.M., Lee, YM. and Lillehoj, E.P. (2007) In vitro treatment of chicken peripheral blood lymphocytes, macrophages, and tumor cells with extracts of Korean medicinal plants. Nutr. Res. Rev., 27(6): 362-366.

139. Lee, S.H., Lillehoj, H.S., Heckert, R.A., Cho, S.M., Tuo, W., Lillehoj E.P., Chun, H.K. and Park, H.J. (2008) Immune enhancing properties of safflower leaf (Carthamus tinctorius) on chicken lymphocytes and macrophages. J. Poult. 
Sci., 45(2): 147-151.

140. Dejene, D.B. (2021) Comprehensive review on turmeric (Curcuma longa L.) as medicinal plants and its nutraceutical quality to human. Cancer Ther. Oncol. Int. J., 18(3): 555990 .
141. Sahin, K., Orhan, C., Tuzcu, M., Sahin, N., Tastan, H., Özercan, I.H., Güler, O., Kahraman, N., Kucuk, O. and Ozpolat, B. (2017) Chemopreventive and antitumor efficacy of curcumin in a spontaneously developing hen ovarian cancer model. Cancer Prev. Res., 11(1): 59-67.

$* * * * * * * *$ 